Olivet Nazarene University

Digital Commons@ Olivet

Student Scholarship - Geology

Geology

Spring 4-27-2018

\title{
Ranking Matthiessen State Park Trails by Hazard Rather Than Difficulty
}

Levi S. Gambill

Olivet Nazarene University, lsgambill@olivet.edu

Danielle N. Conrad

Olivet Nazarene University, dnconrad@olivet.edu

Joshua A. Woodard

Olivet Nazarene University, jawoodard@olivet.edu

Max Reams

Olivet Nazarene University, mreams@olivet.edu

Follow this and additional works at: https://digitalcommons.olivet.edu/geol_stsc

Part of the Geology Commons, Geomorphology Commons, Other Earth Sciences Commons, and the Science and Mathematics Education Commons

\section{Recommended Citation}

Gambill, Levi S.; Conrad, Danielle N.; Woodard, Joshua A.; and Reams, Max, "Ranking Matthiessen State Park Trails by Hazard Rather Than Difficulty" (2018). Student Scholarship - Geology. 1.

https://digitalcommons.olivet.edu/geol_stsc/1

This Article is brought to you for free and open access by the Geology at Digital Commons @ Olivet. It has been accepted for inclusion in Student Scholarship - Geology by an authorized administrator of Digital Commons @ Olivet. For more information, please contact

digitalcommons@olivet.edu. 
Ranking Matthiessen State Park Trails by Hazard Rather Than Difficulty

\author{
By: \\ Levi Gambill \\ Danielle Conrad \\ Josh Woodard
}

Olivet Nazarene University 


\begin{abstract}
Matthiessen State Park offers differing perspectives of the geology of the area, from the stunning views of bluffs and floodplain of the Vermilion River to the deep, winding canyons of the park's Dells Area. A numerical system was used to rank the severity of hazards along the various park trails similar to the work of Ross (2014a, 2014b), who pioneered the ranking of trails by hazard, specifically for Starved Rock State Park. Ross showed that ranking trails by hazard may be more useful for visitors than simply ranking trails by degree of difficulty. Ranking of trails for Matthiessen State Park proved somewhat different from those of Ross, since hazards in the two parks are not exactly the same. The most hazardous trail is the Upper Dells, which is closely related to erosional surfaces. Steep cliffs and drop-offs are especially significant in the specific ranking concerns. It is hoped that such studies will be used to inform visitors of the hazards associated with each trail and enhance the safety of park visits.
\end{abstract}




\section{Introduction}

Natural hazards are threats to humanity created by the natural world. Examples of these would be rockslides, flash floods, and fallen trees. These hazards, and many others, claim thousands of people's lives every year and cost many people large sums of money in property damage. A death count was made from the years 2004 to 2013 by the International Federation of Red Cross and Red Crescent Societies. This death count found that 1,059,072 people were killed as a result of natural hazards (World Disasters Report 2014, 2014). Natural hazards clearly affect human lives on a global scale. State parks are no exception to this. Some state parks do a better job at preventing the natural hazards, but how effective are they at doing such? Our research team set out to answer this question.

Matthiessen State Park is located just off Route 178 in Oglesby, IL. The park is divided into two major areas: the Vermilion River Area and the Dells Area. Both of these areas have a network of paths and trails running throughout them. The stunning views and rich wildlife bring many visitors to this park. However, this park is no stranger to dangerous hazards. In fact, in July of 2002, a person fell to their death due to shear surfaces caused by erosion (Churney, 2006). This research was done to assess the hazards of the park all the while seeing which of the trails would be the most dangerous based on the hazards that are present. Deaths, like the one recently stated, could be prevented if the general public knew about the dangers that lurk underneath their feet. 


\section{Background Information}

Matthiessen State Park started to form during the Ordovician Period, around 488 million years ago. Through the process of deposition, the Ordovician St. Peter Sandstone was laid down. This formation can be seen in the lower parts of the Lower Dells. An unconformity can be seen as the Platteville Dolomite, another Ordovician formation, overlays the St. Peter Sandstone. Other layers of strata are of Pennsylvanian age. These strata consist of alternating layers of shale, sandstone and coal (Ross, 2015). One structural aspect of the area is the LaSalle Anticline. This can be seen in areas carved out by the Vermilion River. Large boulders of granite can be seen dotting the landscape. These are more than likely glacial erratics, mainly because the lithology of Illinois does not contain granite. These boulders are speculated to have been moved by glaciers during the many glacial movements that took place during the Cenozoic Era lasting until the last glacial retreat approximately 10,000 years ago. The main erosional process affecting the area is erosion caused by water. Caves can be seen in the Lower Dells, showing the effects of groundwater flow. There is also evidence of headward erosion caused by the waterfalls in the canyons, this can be seen in Figure 1 below (Reams, 2013).

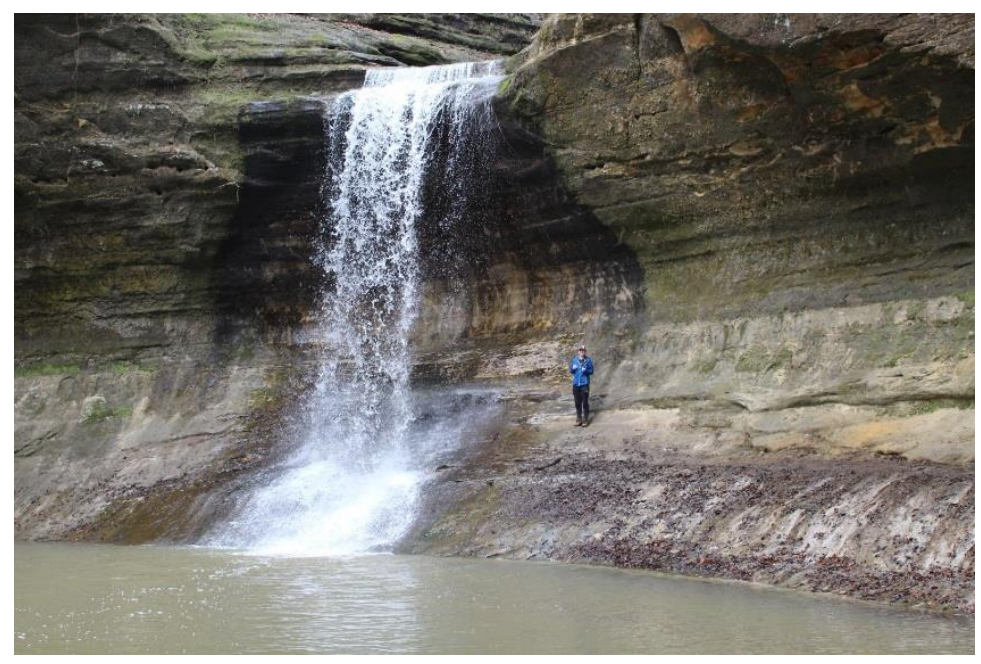

Figure 1: Headward erosion caused by waterfall. 
Matthiessen State Park was purchased by Frederick William Matthiessen at the end of the 19th Century. When the land was purchased, Matthiessen began construction of the park immediately; building bridges, stairways, dams, and trails. When the construction was finished they named the park Deer Park, a nod to the large deer population found in the area. The State of Illinois acquired the park after the death of Mr. Matthiessen. The state in turn named the park after the founder in 1943. The land has since grown and now has 1,938 acres instead of the original 176 acres (Matthiessen State Park, 2017). A current map of the park is located below as well as pictures of the individual areas.

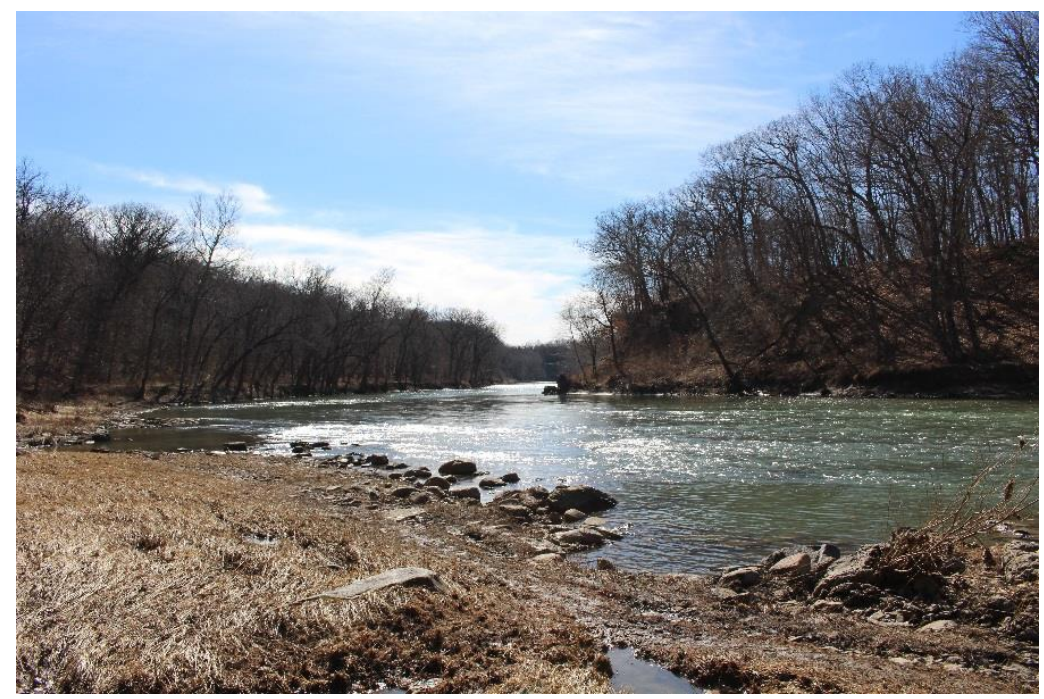

Figure 2: Vermilion River from the Vermilion River Area.

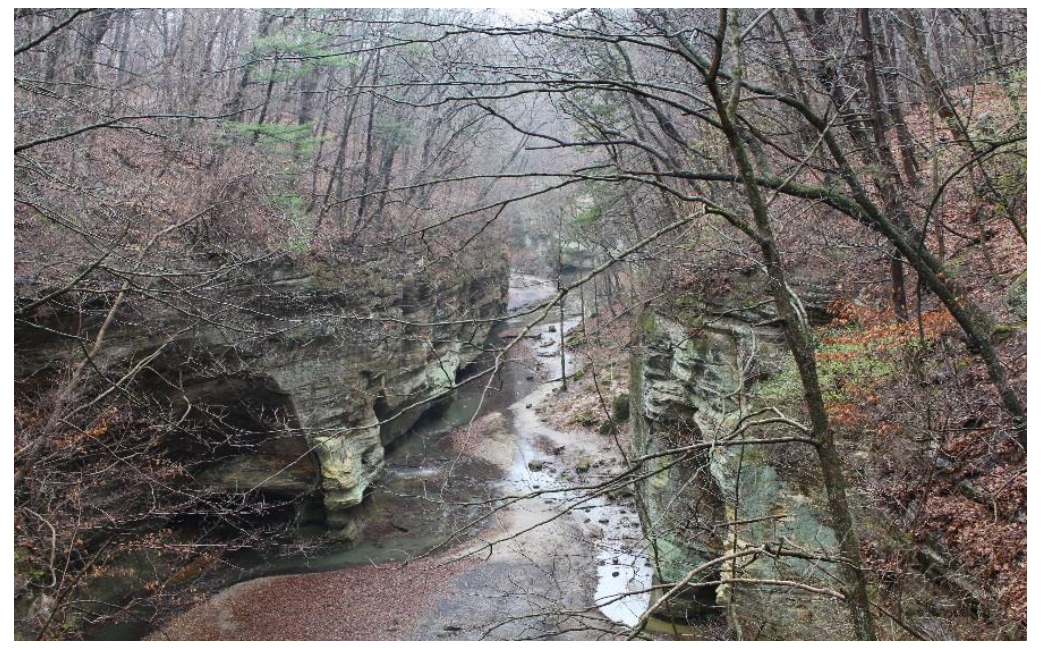

Figure 3: A view of the lower dells from the upper dells of the Dells Area. 


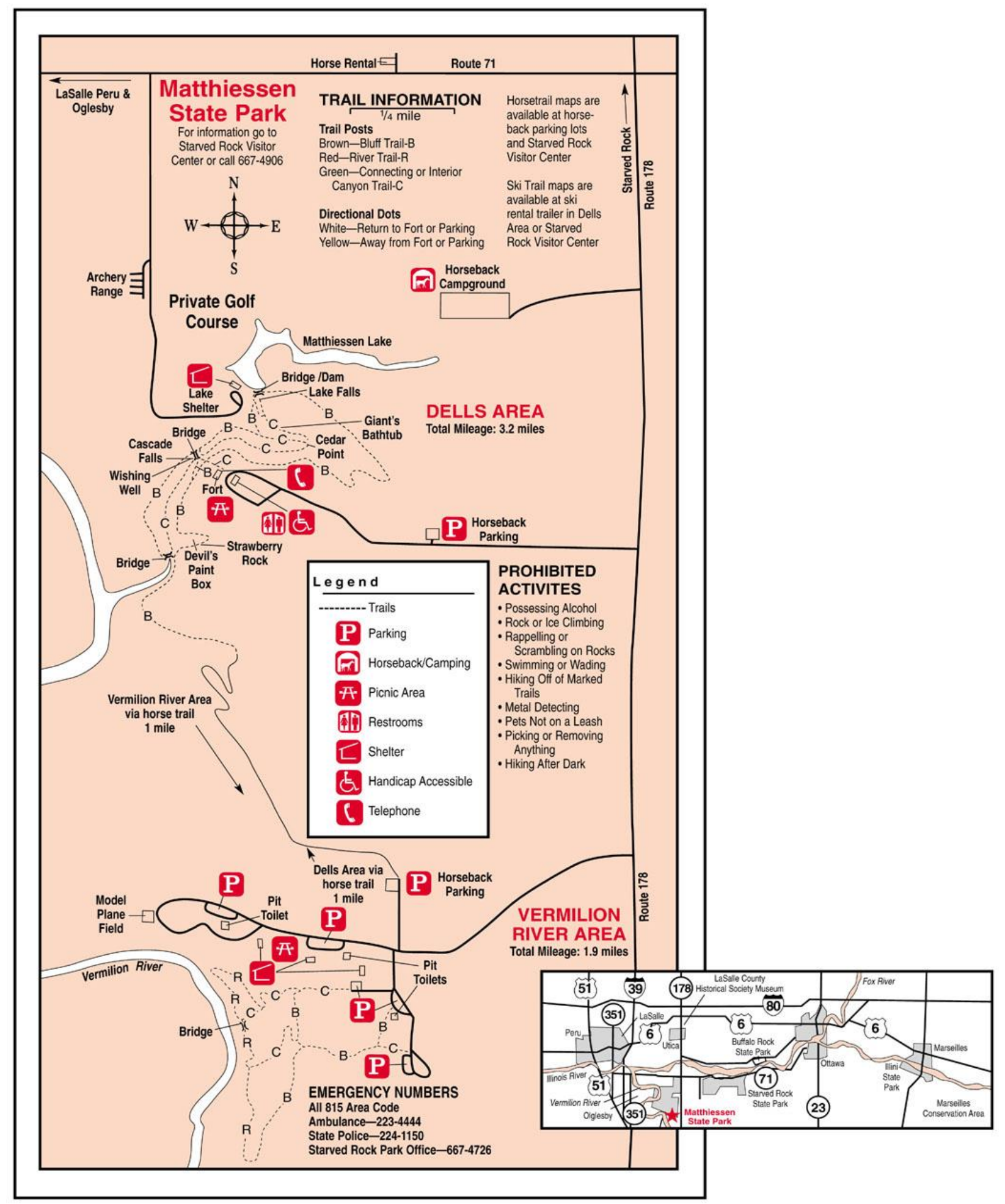

Figure 5: Map of Matthiessen State Park. 


\section{Methods}

For this research project, our research team traveled to Matthiessen State Park to observe and record possible hazards along the trails and pathways that are available for hiking. We observed hazards at the two different locations within the park: The Vermilion River Area and the Dells Area. This was done in both the spring and fall, allowing us to see if more hazards had been created. The difference in time also allowed us to see how the park staff tried to fix any problems with the park. To observe and record specific hazards, our research team hiked each trail and recorded each hazard by using a GPS device to document exact positions and coordinates along the trails. These coordinates were recorded in a field notebook and compiled after our research was completed. The hazards were then given a value, or weight, that was used in the final calculation of the hazard value for each trail. The table below (Table 1) shows how each hazard's weight was calculated. 


\section{Table 1: Hazard Weight Calculation}

\begin{tabular}{|c|c|c|c|c|c|c|c|}
\hline Hazard: & Past Injury & $\begin{array}{l}\text { Future injury } \\
\text { likely? }\end{array}$ & Past Death & $\begin{array}{c}\text { Future } \\
\text { Death likely? }\end{array}$ & $\begin{array}{c}\text { Frequent } \\
\text { occurrences? (At } \\
\text { least once per } \\
\text { year?) }\end{array}$ & Dangerous? & Total: \\
\hline Steep Climbs & 0 & 1 & 0 & 0 & 0 & 0 & 1 \\
\hline Staircase & 0 & 1 & 0 & 0 & 0 & 1 & 2 \\
\hline Fallen Trees & 0 & 1 & 0 & 0 & 0 & 2 & 3 \\
\hline $\begin{array}{r}\text { Erosion/ Shear } \\
\text { Surface }\end{array}$ & 0 & 1 & 1 & 1 & 0 & 3 & 6 \\
\hline Rockfalls & 0 & 1 & 0 & 1 & 0 & 4 & 6 \\
\hline
\end{tabular}


These hazard weights were then used in the new hazard equation our team created. The new equation can be seen in Table 2.

\section{Table 2: Hazard Equation}

$$
\begin{aligned}
& \text { Total Hazard Rating }=[((5 / 1.0 \text { miles }) * x \text { miles })+((3 / 1.0 \text { miles }) * x \text { miles })]+6 \mathrm{E}+2 \mathrm{~S}+6 \mathrm{R}+1 \mathrm{C}+2 \mathrm{~T} \\
& \qquad \mathrm{E}=\text { Erosion/Shear Surface } \\
& \mathrm{S}=\text { Staircase } \\
& \mathrm{R}=\text { Rockfall } \\
& \mathrm{C}=\text { Steep Climb } \\
& \mathrm{T}=\text { Trip/Slip }
\end{aligned}
$$

\begin{tabular}{|c|} 
Table 3: Older Hazard Equation \\
\hline Total Hazard Rating $=1 \mathrm{~F}+3 \mathrm{H}+5 \mathrm{~S}+[(7 / 1.0$ miles $) *(\mathrm{x}$ miles $)]+8 \mathrm{C}+8 \mathrm{R}$ \\
\hline $\mathrm{F}=$ number of flooding/erosion instances along the trail \\
\hline $\mathrm{H}=$ number of High Vantage points along the trail \\
\hline $\mathrm{S}=$ number of major staircases along the trail \\
\hline $\mathrm{X}=$ number of miles of the trail \\
\hline $\mathrm{C}=$ number of canyons along the trail
\end{tabular}

To derive this new equation, our team had to first look at what the old equation was, seen in Table 3 (Ross, 2015). After looking at the old equation, we were able to change a few things while also adding in new values from new hazards that weren't originally considered. The hazards our team used in our equation are: flooding, tree falls, erosion/shear surfaces, staircases, rockfalls, steep climbs, and trip/slips. The flooding hazard was taken when the trail crossed through a floodplain. The hazard value for flooding, 5, was divided by a standard distance of 1 mile and then multiplied by the distance the trail crossed through the floodplain. 
A similar principle was used for determining the hazard value relating to tree falls. Tree falls had a hazard weight of 3 and a point was taken whenever the trail went through a forested area. The weight was then divided by the standard distance of 1 mile and then multiplied by the distance the trail covered while in a forested area. The rest of the hazards were taken as points where the hazard existed, meaning an erosion/shear surface point was taken when our team came across evidences of erosion or a shear surface. A staircase point was taken where staircases existed along the trails, whether they be manmade or natural. A point was taken for rockfalls whenever there was a risk of rocks and debris falling onto or near the trail. Steep climbs points were taken when the trail became laborious to climb due to a steep slope. Lastly, a trip/slip point was taken when objects on the trail or the trail itself ran the risk of either causing a park guest to trip or slip. Examples of each of these hazards can be found in Appendix B. Each of these remaining hazards, erosion/shear surfaces, staircases, rockfalls, steep climbs, and trip/slips, were multiplied by the number of occurrences and then added together with the flooding and tree falls to get a total hazard value for a trail. This total hazard value was compared with each of the trails.

To complete our research, we used the following equipment:

1. Trimble Juno SB (GPS)

2. Field Notebook and Pencil

3. Camera

4. Sample Bag 


\section{Results}

The highest ranking trail for the Vermilion River Area of the state park was River

Trail. River Trail is the longest of the trails and it runs parallel with the river. This leaves the trail susceptible to flooding. This trail also ran along the side of the steep cliffs that form part of the park. There were two sizeable rockfalls about $10+\mathrm{ft}$ away from the trail. Apart from the flooding and rockfalls, there were also streams that crossed over the trail, wearing away at the path. These hazards combined with a risk of falling trees and a steep climb, resulted in the trail receiving a rank of 68.12 . The lowest ranking trail from this area was the Big Hill trail. This trail received a rank of 30.69 due to its short distance and lack of major hazards. The most common hazard of the Vermilion River Area of the park was shear surfaces. Table 4, located below, shows the values for the other trails that were walked and the distance of each trail.

\begin{tabular}{|r|c|c|}
\hline Table 4: Vermilion River Trail Distance and Hazard Value \\
\hline Trail Name & Distance (Miles) & Total Hazard Value \\
\hline Ridge Trail & 0.59 & 63.77 \\
\hline Big Hill Trail & 0.23 & 30.69 \\
\hline River Trail & 0.64 & 68.12 \\
\hline Ziggy Trail & 0.34 & 39.02 \\
\hline
\end{tabular}

The Dells Area of the park had significantly more hazards. The Upper Dells area received a large hazard value of 291.28 . This is mostly due to the overall length of the trail coupled with the large amount of erosion and shear surface points. The Lower Dells received a value of 80.08 . The Lower Dells is located on the inside of the canyons, putting them at a lower elevation. This pathway has flowing streams within it and this part of the dells is known for 
flash floods. Shear surfaces were also the most prevalent hazard in this area of the park. Table 5 shows the length of the trails and the total hazard value.

\begin{tabular}{|r|cc|}
\hline \multicolumn{3}{c}{ Table 5: Dells Area Trail Distance and Hazard Value } \\
\hline Trail Name & Distance (Miles) & Total Hazard Value \\
\hline Upper Dells & 1.76 & 291.28 \\
\hline Lower Dells & 1.01 & 80.08 \\
\hline
\end{tabular}

\section{Discussion}

After careful compilation and analysis of the data recorded, some safety concerns need to be addressed, in general, for Matthiessen State Park trails, as well as more serious concerns for specific trails. Compared to the Dells Area, the Vermilion River Area trails contain fewer hazards, however, there are still some concerns among some of the tails that make up this area. As is stated within the results section, the trail with the largest hazard value is River Trail. This trail ran alongside Vermilion River, and through the floodplain. This puts the trail at considerable risk to flooding. This was evidenced by the presence of thick mud along the trail, gravel and shells carried by water now on land, and large puddles. Hikers and tourists should be careful of river flooding, especially during or after periods of rainfall. River Trail also comes near shear cliffs of sandstone. This puts the trail at a risk for large rockfalls. This is evidenced by two such rockfalls observed already along the trail. Hikers and tourists should be careful for rockfalls at all times. This risk would increase during times of heavy rainfall or during the winter when frost wedging and other mechanical processes are working on the rock faces. Most of the remaining trails of the Vermilion River Area are free of high ranking hazards. The biggest 
concern along these trails would be either risk of falling from shear surfaces or a risk of falling trees.

The Dells Area hazards are more plentiful in number and in risk values. This section of the park is broken up into two large trails: The Upper and Lower Dells. The Upper Dells contains some significant hazards that hikers and tourists should be aware of. The trail continuously runs along the edge of the canyon of the Lower Dells. There are many shear surfaces along the Upper Dells trail. In some areas, the drop off can be very dangerous, especially if there has been recent rainfall, snow or ice fall, or significant erosion in the area. These would all increase the risk of someone falling along one of the shear surfaces. A fall could result in cuts and bruises, fractured or broken bones, or even death. The Upper Dells area also contains several failing supports. Small streams have eroded the rock and soil underneath these supports and a complete failure is likely. This could also result in injuries from shear surfaces. However, the supports appear to a be a short term solution to the problem because the trails are still eroding away due to the supports holding in excess water. The Lower Dells trail received a smaller total hazard value. However, as the trail runs along the bottom of the canyon, flash flooding could be a significant hazard for hikers and tourists. The trail also puts hikers near the shear rock walls and therefore, near future rockfalls.

\section{Conclusion}

By using a numbered system to rank the severity of natural hazards, we determined which trails of Matthiessen were the most hazardous. The highest ranking trail for the 
Vermilion River Area was River Trail and the Upper Dells for the Dells Area. The most common hazard found in both areas were shear surfaces. Shear surfaces, which rank 6 on our scale, are not only dangerous because of their steep slopes, but they can also lead to several problems in the future resulting in more rock falls or destroyed paths. After discovering all of the hazards recorded, it's safe to say that significant work needs to be done to the failed supports and erosional features of the trails to prevent additional hazards or injuries. One possible solution is to increase the effectiveness of drainage pipes since the majority of the pipes examined were clogged or broken. This would allow water that is flooding and eroding the paths to be transferred under the path directly to a lower elevation, thereby preserving the trails and increasing safety. Another possible solution is to add effective railings or fences at shear faces and replace the visible failing supports. In worse case scenarios, the park employees could close down the dangerous trails and create safer new ones. These possible solutions would greatly increase the safety of the park. This, in turn, would make the park more enjoyable and help to preserve the park over generations, allowing many to continue to enjoy the natural wonders of Matthiessen State Park. 


\section{References}

Churney, D. (2006, May 2). Starved Rock: Fatal Fall Focuses Attention on Trails. Retrieved from http://www.mywebtimes.com/news/local/starved-rock-fatal-fall-focuses-attention-ontrails/article_863b999b-4d9a-5aea-b795-27df90df39dd.html

Illinois State Geological Survey, 2005, Time talks: The Geology of Starved Rock and Matthiessen State Parks, Illinois State Geological Survey, 50 P.

Matthiessen State Park. (2017). Retrieved from http://www.stateparks.com/matthiessen.html Reams, M. W. (2013). Geology of Illinois State Parks. Lexington, Kansas. 57 P.

Ross, J. K. (2015). Ranking Trails Based on Natural Hazards Instead of Difficulty: A Case Study on Starved Rock State Park. (Unpublished undergraduate thesis). Olivet Nazarene University, Bourbonnais, II.

World Disasters Report 2014 - Data. (2014). Retrieved from http://www.ifrc.org/worlddisasters-report-2014/data 
Appendix A: Additional Data

\begin{tabular}{|c|c|c|c|c|}
\hline \multicolumn{5}{|c|}{ Data Collected from Vermilion River Area } \\
\hline Point & Type & GPS & $\begin{array}{c}\text { Trail } \\
\text { Name }\end{array}$ & Value \\
\hline 1 & Shear Surface & $41^{\circ} 16^{\prime} 45.387^{\prime \prime} \mathrm{N}, 89^{\circ} 01^{\prime} 26.395^{\prime \prime} \mathrm{W}$ & Ridge Trail & 6 \\
\hline 2 & Shear Surface & $41^{\circ} 16^{\prime} 46.293^{\prime \prime} \mathrm{N}, 89^{\circ} 01^{\prime} 26.247^{\prime \prime} \mathrm{W}$ & Ridge Trail & 6 \\
\hline 3 & Shear Surface & $41^{\circ} 16^{\prime} 46.497^{\prime \prime} \mathrm{N}, 89^{\circ} 01^{\prime} 26.268^{\prime \prime} \mathrm{W}$ & Ridge Trail & 6 \\
\hline 4 & Erosion & $41^{\circ} 16^{\prime} 47.685^{\prime \prime} \mathrm{N}, 89^{\circ} 01^{\prime} 27.784^{\prime \prime} \mathrm{W}$ & Ridge Trail & 6 \\
\hline 5 & Shear Surface & $41^{\circ} 16^{\prime} 34.202^{\prime \prime} \mathrm{N}, 8^{\circ} 01^{\prime} 29.861^{\prime \prime} \mathrm{W}$ & Ridge Trail & 6 \\
\hline 6 & Erosion & $41^{\circ} 16^{\prime} 39.659^{\prime \prime} \mathrm{N} 89^{\circ} 1^{\prime} 26.695^{\prime \prime} \mathrm{W}$ & Ridge Trail & 6 \\
\hline 7 & Shear Surface & $41^{\circ} 16^{\prime} 37.574^{\prime \prime} \mathrm{N} 89^{\circ} 1^{\prime} 26.493$ "W & Ridge Trail & 6 \\
\hline 8 & Shear Surface & $41^{\circ} 16^{\prime} 35.8^{\prime \prime} \mathrm{N} 89^{\circ} 1^{\prime} 26.9^{\prime \prime} \mathrm{W}$ & Ridge Trail & 6 \\
\hline 9 & Shear Surface & $41^{\circ} 16^{\prime} 33.179^{\prime \prime} \mathrm{N} 89^{\circ} 1^{\prime} 29.092^{\prime \prime W}$ & Ridge Trail & 6 \\
\hline 10 & Erosion & $41^{\circ} 16^{\prime} 32.196^{\prime \prime} \mathrm{N} 89^{\circ} 1^{\prime} 30.45^{\prime \prime W}$ & Ridge Trail & 6 \\
\hline 11 & Staircase & $41^{\circ} 16^{\prime} 30.101^{\prime \prime N} 89^{\circ} 1^{\prime} 31.09^{\prime \prime W}$ & Ridge Trail & 2 \\
\hline 12 & Shear Surface & $41^{\circ} 16^{\prime} 47.662^{\prime \prime} \mathrm{N}, 89^{\circ} 01^{\prime} 27.423^{\prime \prime} \mathrm{W}$ & Big Hill Trail & 6 \\
\hline 13 & Shear Surface & $41^{\circ} 16^{\prime} 47.113^{\prime \prime} \mathrm{N}, 89^{\circ} 01^{\prime} 30.755^{\prime \prime} \mathrm{W}$ & Big Hill Trail & 6 \\
\hline 14 & Trip/Slip & $41^{\circ} 16^{\prime} 45.534^{\prime \prime} \mathrm{N}, 89^{\circ} 01^{\prime} 29.432^{\prime \prime} \mathrm{W}$ & Big Hill Trail & 2 \\
\hline 15 & Trip/Slip & $41^{\circ} 16^{\prime} 45.502^{\prime \prime} \mathrm{N}, 89^{\circ} 01^{\prime} 29.823^{\prime \prime} \mathrm{W}$ & Big Hill Trail & 2 \\
\hline 16 & Steep Climb & $41^{\circ} 16^{\prime} 46.25^{\prime \prime} \mathrm{N} 89^{\circ} 1^{\prime} 30.259^{\prime \prime} \mathrm{W}$ & Big Hill Trail & 1 \\
\hline 17 & Shear Surface & $41^{\circ} 16^{\prime} 46.25^{\prime \prime} \mathrm{N} 89^{\circ} 1^{\prime} 30.259^{\prime \prime} \mathrm{W}$ & Big Hill Trail & 6 \\
\hline 18 & Erosion & $41^{\circ} 16^{\prime} 46.978^{\prime \prime} \mathrm{N} 89^{\circ} 1^{\prime} 30.338^{\prime \prime} \mathrm{W}$ & Big Hill Trail & 6 \\
\hline 19 & Steep Climb & $41^{\circ} 16^{\prime} 47.55^{\prime \prime} \mathrm{N} 89^{\circ} 1^{\prime} 27.933^{\prime \prime W}$ & Big Hill Trail & 1 \\
\hline 20 & Fallen Tree & $41^{\circ} 16^{\prime} 48.905^{\prime \prime} \mathrm{N}, 89^{\circ} 01^{\prime} 35.365^{\prime \prime} \mathrm{W}$ & River Trail & 3 \\
\hline 21 & Rock Fall & $41^{\circ} 16^{\prime} 50.124^{\prime \prime} \mathrm{N}, 89^{\circ} 01^{\prime} 36.754^{\prime \prime} \mathrm{W}$ & River Trail & 6 \\
\hline 22 & Rock Fall & $41^{\circ} 16^{\prime} 50.863^{\prime \prime} \mathrm{N}, 89^{\circ} 01^{\prime} 38.240^{\prime \prime} \mathrm{W}$ & River Trail & 6 \\
\hline 23 & Flooding & $41^{\circ} 16^{\prime} 49.309^{\prime \prime} \mathrm{N}, 89^{\circ} 01^{\prime} 38.044^{\prime \prime} \mathrm{W}$ & River Trail & 5 \\
\hline 24 & Shear Surface & $41^{\circ} 16^{\prime} 44.231^{\prime \prime} \mathrm{N}, 89^{\circ} 01^{\prime} 33.508^{\prime \prime} \mathrm{W}$ & River Trail & 6 \\
\hline 25 & Flooding & $41^{\circ} 16^{\prime} 43.825^{\prime \prime} \mathrm{N}, 89^{\circ} 01^{\prime} 33.227^{\prime \prime} \mathrm{W}$ & River Trail & 5 \\
\hline 26 & Flooding & $41^{\circ} 16^{\prime} 39.498^{\prime \prime} \mathrm{N}, 89^{\circ} 01^{\prime} 32.075^{\prime \prime} \mathrm{W}$ & River Trail & 5 \\
\hline 27 & Flooding & $41^{\circ} 16^{\prime} 38.727^{\prime \prime} \mathrm{N}, 89^{\circ} 01^{\prime} 32.388^{\prime \prime} \mathrm{W}$ & River Trail & 5 \\
\hline 28 & Steep Climb & $41^{\circ} 16^{\prime} 32.106^{\prime \prime} \mathrm{N}, 89^{\circ} 01^{\prime} 34.900^{\prime \prime} \mathrm{W}$ & River Trail & 1 \\
\hline 29 & Erosion & $41^{\circ} 16^{\prime} 28.632^{\prime \prime} \mathrm{N} 89^{\circ} 1^{\prime} 29.765^{\prime \prime} \mathrm{W}$ & River Trail & 6 \\
\hline 30 & Erosion & $41^{\circ} 16^{\prime} 28.582^{\prime \prime} \mathrm{N} 89^{\circ} 1^{\prime} 33.571^{\prime \prime} \mathrm{W}$ & River Trail & 6 \\
\hline 31 & Steep Climb & $41^{\circ} 16^{\prime} 30.716^{\prime \prime} \mathrm{N} 89^{\circ} 1^{\prime} 35.49^{\prime \prime} \mathrm{W}$ & River Trail & 1 \\
\hline 32 & Erosion & $41^{\circ} 16^{\prime} 30.716^{\prime \prime} \mathrm{N} 89^{\circ} 1^{\prime} 35.49^{\prime \prime} \mathrm{W}$ & River Trail & 6 \\
\hline 33 & Fallen Tree & $41^{\circ} 16^{\prime} 33.802^{\prime \prime} \mathrm{N} 89^{\circ} 1^{\prime} 35.742^{\prime \prime} \mathrm{W}$ & River Trail & 3 \\
\hline
\end{tabular}




\begin{tabular}{|c|c|c|c|c|}
34 & Erosion & $41^{\circ} 16^{\prime} 35.951^{\prime \prime} \mathrm{N} 89^{\circ} 1^{\prime} 32.574 " \mathrm{~W}$ & River Trail & 6 \\
\hline 35 & Erosion & $41^{\circ} 16^{\prime} 43.514^{\prime \prime} \mathrm{N} 89^{\circ} 1^{\prime} 33.024^{\prime \prime} \mathrm{W}$ & River Trail & 6 \\
\hline 36 & Flooding & $41^{\circ} 16^{\prime} 43.619^{\prime \prime} \mathrm{N} 89^{\circ} 1^{\prime} 33.204^{\prime \prime} \mathrm{W}$ & River Trail & 5 \\
\hline 37 & Steep Climb & $41^{\circ} 16^{\prime} 43.968^{\prime \prime} \mathrm{N} 89^{\circ} 1^{\prime} 33.225^{\prime \prime} \mathrm{W}$ & River Trail & 1 \\
\hline 38 & Shear Surface & $41^{\circ} 16^{\prime} 43.968^{\prime \prime} \mathrm{N} 89^{\circ} 1^{\prime} 33.225^{\prime \prime} \mathrm{W}$ & River Trail & 6 \\
\hline 39 & Erosion & $41^{\circ} 16^{\prime} 48.284^{\prime \prime} \mathrm{N} 89^{\circ} 1^{\prime} 36.375^{\prime \prime} \mathrm{W}$ & River Trail & 6 \\
\hline 40 & Erosion & $41^{\circ} 16^{\prime} 40.641^{\prime \prime} \mathrm{N}, 89^{\circ} 01^{\prime} 28.596^{\prime \prime} \mathrm{W}$ & Ziggy Trail & 6 \\
\hline 41 & Erosion & $41^{\circ} 16^{\prime} 31.133^{\prime \prime} \mathrm{N}, 89^{\circ} 01^{\prime} 31.942^{\prime \prime} \mathrm{W}$ & Ziggy Trail & 6 \\
\hline 42 & Steep Climb & $41^{\circ} 16^{\prime} 28.765^{\prime \prime} \mathrm{N} 89^{\circ} 1^{\prime} 33.556^{\prime \prime} \mathrm{W}$ & Ziggy Trail & 1 \\
\hline 43 & Fallen Tree & $41^{\circ} 16^{\prime} 32.549^{\prime \prime} \mathrm{N} 89^{\circ} 1^{\prime} 31.08^{\prime \prime} \mathrm{W}$ & Ziggy Trail & 3 \\
\hline 44 & Trip/Slip & $41^{\circ} 16^{\prime} 32.549^{\prime \prime} \mathrm{N} 89^{\circ} 1^{\prime} 31.08^{\prime \prime} \mathrm{W}$ & Ziggy Trail & 2 \\
\hline 45 & Shear Surface & $41^{\circ} 16^{\prime} 33.989^{\prime \prime} \mathrm{N} 89^{\circ} 1^{\prime} 29.557^{\prime \prime} \mathrm{W}$ & Ziggy Trail & 6 \\
\hline 46 & Rock Fall & $41^{\circ} 16^{\prime} 34.709^{\prime \prime} \mathrm{N} 89^{\circ} 1^{\prime} 29.395^{\prime \prime} \mathrm{W}$ & Ziggy Trail & 6 \\
\hline 47 & Fallen Tree & $41^{\circ} 16^{\prime} 38.863^{\prime \prime} \mathrm{N} 89^{\circ} 1^{\prime} 27.487^{\prime \prime} \mathrm{W}$ & Ziggy Trail & 3 \\
\hline 48 & Erosion & $41^{\circ} 16^{\prime} 38.863^{\prime \prime} \mathrm{N} 89^{\circ} 1^{\prime} 27.487^{\prime \prime} \mathrm{W}$ & Ziggy Trail & 6 \\
\hline 49 & Erosion & $41^{\circ} 16^{\prime} 39.828^{\prime \prime} \mathrm{N} 89^{\circ} 1^{\prime} 27.443^{\prime \prime} \mathrm{W}$ & Ziggy Trail & 6 \\
\hline
\end{tabular}

\begin{tabular}{|c|c|c|c|c|}
\hline \multicolumn{5}{|c|}{ Data from Dells Area } \\
\hline Point & Type & GPS & Trail Name & Value \\
\hline 1 & Fallen Tree & $41^{\circ} 17^{\prime} 56.09^{\prime \prime} \mathrm{N}, 89^{\circ} 1^{\prime} 24.59^{\prime \prime} \mathrm{W}$ & Upper Dells & 3 \\
\hline 2 & Fallen Tree & $41^{\circ} 17^{\prime} 54.78^{\prime \prime} \mathrm{N}, 89^{\circ} 1^{\prime} 22.07^{\prime \prime} \mathrm{W}$ & Upper Dells & 3 \\
\hline 3 & Shear Surface & $41^{\circ} 17^{\prime} 48.96^{\prime \prime} \mathrm{N}, 89^{\circ} 1^{\prime} 13.31^{\prime \prime} \mathrm{W}$ & Upper Dells & 6 \\
\hline 4 & Erosion & $41^{\circ} 17^{\prime} 47.33^{\prime \prime} \mathrm{N}, 89^{\circ} 1^{\prime} 11.42^{\prime \prime} \mathrm{W}$ & Upper Dells & 6 \\
\hline 5 & Erosion & $41^{\circ} 17^{\prime} 47.21^{\prime \prime} \mathrm{N}, 89^{\circ} 1^{\prime} 12.91^{\prime \prime} \mathrm{W}$ & Upper Dells & 6 \\
\hline 6 & Trip/Slip & $41^{\circ} 17^{\prime} 47.21^{\prime \prime} \mathrm{N}, 89^{\circ} 11^{\prime} 12.91^{\prime \prime} \mathrm{W}$ & Upper Dells & 2 \\
\hline 7 & Shear Surface & $41^{\circ} 17^{\prime} 47.30^{\prime \prime} \mathrm{N}, 89^{\circ} 1^{\prime} 13.70^{\prime \prime} \mathrm{W}$ & Upper Dells & 6 \\
\hline 8 & Trip/Slip & $41^{\circ} 17^{\prime} 48.18^{\prime \prime} \mathrm{N}, 89^{\circ} 1^{\prime} 15.50^{\prime \prime} \mathrm{W}$ & Upper Dells & 2 \\
\hline 9 & Erosion & $41^{\circ} 17^{\prime} 48.18^{\prime \prime} \mathrm{N}, 89^{\circ} 1^{\prime} 15.50^{\prime \prime} \mathrm{W}$ & Upper Dells & 6 \\
\hline 10 & Shear Surface & $41^{\circ} 17^{\prime} 48.01^{\prime \prime} \mathrm{N}, 89^{\circ} 1^{\prime} 18.06^{\prime \prime} \mathrm{W}$ & Upper Dells & 6 \\
\hline 11 & Erosion & $41^{\circ} 17^{\prime} 46.44^{\prime \prime} \mathrm{N}, 89^{\circ} 1^{\prime} 16.20^{\prime \prime} \mathrm{W}$ & Upper Dells & 6 \\
\hline 12 & Trip/Slip & $41^{\circ} 17^{\prime} 46.44^{\prime \prime} \mathrm{N}, 89^{\circ} 1^{\prime} 16.20^{\prime \prime} \mathrm{W}$ & Upper Dells & 2 \\
\hline 13 & Fallen Tree & $41^{\circ} 17^{\prime} 46.70^{\prime \prime} \mathrm{N}, 89^{\circ} 11^{\prime} 18.05^{\prime \prime} \mathrm{W}$ & Upper Dells & 3 \\
\hline 14 & Shear Surface & $41^{\circ} 17^{\prime} 42.18^{\prime \prime} \mathrm{N}, 89^{\circ} 1^{\prime} 19.25^{\prime \prime} \mathrm{W}$ & Upper Dells & 6 \\
\hline 15 & Shear Surface & $41^{\circ} 17^{\prime} 48.47^{\prime \prime} \mathrm{N}, 89^{\circ} 1^{\prime} 20.75^{\prime \prime} \mathrm{W}$ & Upper Dells & 6 \\
\hline 16 & Trip/Slip & $41^{\circ} 17^{\prime} 48.47^{\prime \prime} \mathrm{N}, 89^{\circ} 1^{\prime} 20.75^{\prime \prime} \mathrm{W}$ & Upper Dells & 2 \\
\hline
\end{tabular}




\begin{tabular}{|c|c|c|c|c|}
\hline 17 & Shear Surface & $41^{\circ} 17^{\prime} 48.72^{\prime \prime} \mathrm{N}, 89^{\circ} 1^{\prime} 21.23^{\prime \prime} \mathrm{W}$ & Upper Dells & 6 \\
\hline 18 & Trip/Slip & $41^{\circ} 17^{\prime} 48.72^{\prime \prime} \mathrm{N}, 89^{\circ} 1^{\prime} 21.23^{\prime \prime} \mathrm{W}$ & Upper Dells & 2 \\
\hline 19 & Shear Surface & $41^{\circ} 17^{\prime} 48.69^{\prime \prime} \mathrm{N}, 89^{\circ} 1^{\prime} 22.28^{\prime \prime} \mathrm{W}$ & Upper Dells & 6 \\
\hline 20 & Trip/Slip & $41^{\circ} 17^{\prime} 48.69^{\prime \prime} \mathrm{N}, 89^{\circ} 1^{\prime} 22.28^{\prime \prime} \mathrm{W}$ & Upper Dells & 2 \\
\hline 21 & Shear Surface & $41^{\circ} 17^{\prime} 49.57^{\prime \prime} \mathrm{N}, 89^{\circ} 1^{\prime} 23.09^{\prime \prime} \mathrm{W}$ & Upper Dells & 6 \\
\hline 22 & Erosion & $41^{\circ} 17^{\prime} 49.28^{\prime \prime} \mathrm{N}, 89^{\circ} 1^{\prime} 25.51^{\prime \prime} \mathrm{W}$ & Upper Dells & 6 \\
\hline 23 & Shear Surface & $41^{\circ} 17^{\prime} 49.28^{\prime \prime} \mathrm{N}, 89^{\circ} 1^{\prime} 25.51^{\prime \prime} \mathrm{W}$ & Upper Dells & 6 \\
\hline 24 & Erosion & $41^{\circ} 17^{\prime} 48.54^{\prime \prime} \mathrm{N}, 89^{\circ} 1^{\prime} 26.79^{\prime \prime} \mathrm{W}$ & Upper Dells & 6 \\
\hline 25 & Shear Surface & $41^{\circ} 17^{\prime} 48.79^{\prime \prime} \mathrm{N}, 89^{\circ} 1 ' 26.82^{\prime \prime} \mathrm{W}$ & Upper Dells & 6 \\
\hline 26 & Trip/Slip & $41^{\circ} 17^{\prime} 48.79^{\prime \prime} \mathrm{N}, 89^{\circ} 1 ' 26.82^{\prime \prime} \mathrm{W}$ & Upper Dells & 2 \\
\hline 27 & Shear Surface & $41^{\circ} 17^{\prime} 48.77^{\prime \prime} \mathrm{N}, 89^{\circ} 1$ '31.34" W & Upper Dells & 6 \\
\hline 28 & Failing Support & $41^{\circ} 17^{\prime} 48.77^{\prime \prime} \mathrm{N}, 89^{\circ} 1^{\prime} 31.34^{\prime \prime} \mathrm{W}$ & Upper Dells & \\
\hline 29 & Shear Surface & $41^{\circ} 17^{\prime} 50.26^{\prime \prime} \mathrm{N}, 89^{\circ} 1{ }^{\prime} 32.78^{\prime \prime} \mathrm{W}$ & Upper Dells & 6 \\
\hline 30 & Shear Surface & $41^{\circ} 17^{\prime} 50.14^{\prime \prime} \mathrm{N}, 89^{\circ} 1$ '35.09" W & Upper Dells & 6 \\
\hline 31 & Shear Surface & $41^{\circ} 17^{\prime} 49.57^{\prime \prime} \mathrm{N}, 89^{\circ} 1^{\prime} 35.90^{\prime \prime} \mathrm{W}$ & Upper Dells & 6 \\
\hline 32 & Trip/Slip & $41^{\circ} 17^{\prime} 49.38^{\prime \prime} \mathrm{N}, 89^{\circ} 1^{\prime} 38.73^{\prime \prime} \mathrm{W}$ & Upper Dells & 2 \\
\hline 33 & Erosion & $41^{\circ} 17^{\prime} 46.57^{\prime \prime} \mathrm{N}, 89^{\circ} 1^{\prime} 39.31^{\prime \prime} \mathrm{W}$ & Upper Dells & 6 \\
\hline 34 & Shear Surface & $41^{\circ} 17^{\prime} 46.57^{\prime \prime} \mathrm{N}, 89^{\circ} 1^{\prime} 39.31^{\prime \prime} \mathrm{W}$ & Upper Dells & 6 \\
\hline 35 & Erosion & $41^{\circ} 17^{\prime} 40.61^{\prime \prime} \mathrm{N}, 89^{\circ} 1^{\prime} 40.19^{\prime \prime} \mathrm{W}$ & Upper Dells & 6 \\
\hline 36 & Rock Fall & $41^{\circ} 17^{\prime} 40.61^{\prime \prime} \mathrm{N}, 89^{\circ} 1^{\prime} 40.19^{\prime \prime} \mathrm{W}$ & Upper Dells & 6 \\
\hline 37 & Shear Surface & $41^{\circ} 17^{\prime} 40.97^{\prime \prime} \mathrm{N}, 89^{\circ} 1{ }^{\prime} 38.77^{\prime \prime} \mathrm{W}$ & Upper Dells & 6 \\
\hline 38 & Failing Support & $41^{\circ} 17^{\prime} 40.97^{\prime \prime} \mathrm{N}, 89^{\circ} 1{ }^{\prime} 38.77^{\prime \prime} \mathrm{W}$ & Upper Dells & \\
\hline 39 & Trip/Slip & $41^{\circ} 17^{\prime} 40.97^{\prime \prime} \mathrm{N}, 89^{\circ} 1^{\prime} 38.77^{\prime \prime} \mathrm{W}$ & Upper Dells & 2 \\
\hline 40 & Rock Fall & $41^{\circ} 17^{\prime} 40.72^{\prime \prime} \mathrm{N}, 89^{\circ} 1^{\prime} 36.63^{\prime \prime} \mathrm{W}$ & Upper Dells & 6 \\
\hline 41 & Rock Fall & $41^{\circ} 17^{\prime} 39.96^{\prime \prime} \mathrm{N}, 89^{\circ} 1^{\prime} 36.74^{\prime \prime} \mathrm{W}$ & Upper Dells & 6 \\
\hline 42 & Failing Support & $41^{\circ} 17^{\prime} 39.60^{\prime \prime} \mathrm{N}, 89^{\circ} 1^{\prime} 37.81^{\prime \prime} \mathrm{W}$ & Upper Dells & \\
\hline 43 & Erosion & $41^{\circ} 17^{\prime} 39.60^{\prime \prime} \mathrm{N}, 89^{\circ} 1^{\prime} 37.81^{\prime \prime} \mathrm{W}$ & Upper Dells & 6 \\
\hline 44 & Shear Surface & $41^{\circ} 17^{\prime} 39.60^{\prime \prime} \mathrm{N}, 89^{\circ} 1$ '37.81" W & Upper Dells & 6 \\
\hline 45 & Shear Surface & $41^{\circ} 17^{\prime} 49.26^{\prime \prime} \mathrm{N}, 89^{\circ} 1^{\prime} 38.87^{\prime \prime} \mathrm{W}$ & Upper Dells & 6 \\
\hline 46 & Erosion & $41^{\circ} 17^{\prime} 38.19^{\prime \prime} \mathrm{N}, 89^{\circ} 1^{\prime} 41.82^{\prime \prime} \mathrm{W}$ & Upper Dells & 6 \\
\hline 47 & Failing Support & $41^{\circ} 17^{\prime} 38.77^{\prime \prime} \mathrm{N}, 89^{\circ} 1^{\prime} 43.61^{\prime \prime} \mathrm{W}$ & Upper Dells & \\
\hline 48 & Trip/Slip & $41^{\circ} 17^{\prime} 45.40^{\prime \prime} \mathrm{N}, 89^{\circ} 1^{\prime} 43.78^{\prime \prime} \mathrm{W}$ & Upper Dells & 2 \\
\hline 49 & Staircase & $41^{\circ} 17^{\prime} 47.753^{\prime \prime} \mathrm{N} 89^{\circ} 1^{\prime} 34.946^{\prime \prime} \mathrm{W}$ & Upper Dells & 2 \\
\hline
\end{tabular}




\begin{tabular}{|c|c|c|c|c|}
\hline 50 & Shear Surface & $41^{\circ} 17^{\prime} 50.428^{\prime \prime} \mathrm{N} 89^{\circ} 1^{\prime} 33.153^{\prime \prime} \mathrm{W}$ & Upper Dells & 6 \\
\hline 51 & Erosion & $41^{\circ} 17^{\prime} 49.02^{\prime \prime} \mathrm{N} 89^{\circ} 1^{\prime} 31.602^{\prime \prime} \mathrm{W}$ & Upper Dells & 6 \\
\hline 52 & Shear Surface & $41^{\circ} 17^{\prime} 48.854^{\prime \prime} \mathrm{N} 89^{\circ} 1^{\prime} 29.805^{\prime \prime} \mathrm{W}$ & Upper Dells & 6 \\
\hline 53 & Erosion & $41^{\circ} 17^{\prime} 48.523^{\prime \prime} \mathrm{N} 89^{\circ} 1^{\prime} 26.997^{\prime \prime} \mathrm{W}$ & Upper Dells & 6 \\
\hline 54 & Shear Surface & $41^{\circ} 17^{\prime} 48.523^{\prime \prime} \mathrm{N} 89^{\circ} 1^{\prime} 26.997^{\prime \prime} \mathrm{W}$ & Upper Dells & 6 \\
\hline 55 & Shear Surface & $41^{\circ} 17^{\prime} 49.204^{\prime \prime N ~} 89^{\circ} 1^{\prime} 25.309^{\prime \prime} \mathrm{W}$ & Upper Dells & 6 \\
\hline 56 & Fallen Tree & $41^{\circ} 17^{\prime} 49.333^{\prime \prime} \mathrm{N} 89^{\circ} 1^{\prime} 22.904^{\prime \prime} \mathrm{W}$ & Upper Dells & 3 \\
\hline 57 & Erosion & $41^{\circ} 17^{\prime} 48.926^{\prime \prime} \mathrm{N} 89^{\circ} 1^{\prime} 22.619^{\prime \prime} \mathrm{W}$ & Upper Dells & 6 \\
\hline 58 & Erosion & $41^{\circ} 17^{\prime} 48.66^{\prime \prime} \mathrm{N} 89^{\circ} 1^{\prime} 21.183^{\prime \prime} \mathrm{W}$ & Upper Dells & 6 \\
\hline 59 & Erosion & $41^{\circ} 17^{\prime} 47.087^{\prime \prime} \mathrm{N} 89^{\circ} 1^{\prime} 19.304^{\prime \prime} \mathrm{W}$ & Upper Dells & 6 \\
\hline 60 & Shear Surface & $41^{\circ} 17^{\prime} 47.616^{\prime \prime} \mathrm{N} 89^{\circ} 1^{\prime} 13.864^{\prime \prime} \mathrm{W}$ & Upper Dells & 6 \\
\hline 61 & Erosion & $41^{\circ} 17^{\prime} 47.616^{\prime \prime} \mathrm{N} 89^{\circ} 1^{\prime} 13.864^{\prime \prime} \mathrm{W}$ & Upper Dells & 6 \\
\hline 62 & Fallen Tree & $41^{\circ} 17^{\prime} 56.782^{\prime \prime} \mathrm{N} 89^{\circ} 1^{\prime} 25.176^{\prime \prime} \mathrm{W}$ & Upper Dells & 3 \\
\hline 63 & Staircase & $41^{\circ} 17^{\prime} 54.665^{\prime \prime} \mathrm{N} 89^{\circ} 1^{\prime} 31.288^{\prime \prime} \mathrm{W}$ & Upper Dells & 2 \\
\hline 64 & Shear Surface & $41^{\circ} 17^{\prime} 54.665^{\prime \prime} \mathrm{N} 89^{\circ} 1^{\prime} 31.288^{\prime \prime} \mathrm{W}$ & Upper Dells & 6 \\
\hline 65 & Fallen Tree & $41^{\circ} 17^{\prime} 52.13^{\prime \prime} \mathrm{N} 89^{\circ} 1^{\prime} 35.734^{\prime \prime} \mathrm{W}$ & Upper Dells & 3 \\
\hline 66 & Fallen Tree & $41^{\circ} 17^{\prime} 42.954^{\prime \prime} \mathrm{N} 89^{\circ} 1^{\prime} 45.703^{\prime \prime} \mathrm{W}$ & Upper Dells & 3 \\
\hline 67 & Staircase & $41^{\circ} 17^{\prime} 41.795^{\prime \prime} \mathrm{N} 89^{\circ} 1^{\prime} 45.901^{\prime \prime} \mathrm{W}$ & Upper Dells & 2 \\
\hline 68 & Staircase & $41^{\circ} 17^{\prime} 38.148^{\prime \prime} \mathrm{N} 89^{\circ} 1^{\prime} 41.858^{\prime \prime} \mathrm{W}$ & Upper Dells & 2 \\
\hline 69 & Rock Fall & $41^{\circ} 17^{\prime} 39.86^{\prime \prime} \mathrm{N}, 89^{\circ} 1^{\prime} 43.18^{\prime \prime} \mathrm{W}$ & Lower Dells & 6 \\
\hline 70 & Rock Fall & $41^{\circ} 17^{\prime} 44.82^{\prime \prime} \mathrm{N}, 89^{\circ} 1^{\prime} 42.70^{\prime \prime} \mathrm{W}$ & Lower Dells & 6 \\
\hline 71 & Rock Fall & $41^{\circ} 17^{\prime} 45.96^{\prime \prime} \mathrm{N}, 89^{\circ} 1^{\prime} 42.17^{\prime \prime} \mathrm{W}$ & Lower Dells & 6 \\
\hline 72 & Staircase & $41^{\circ} 17^{\prime} 49.988^{\prime \prime N} 89^{\circ} 1^{\prime} 38.524^{\prime \prime} \mathrm{W}$ & Lower Dells & 2 \\
\hline 73 & Flooding & $41^{\circ} 17^{\prime} 51.533^{\prime \prime N ~} 89^{\circ} 1^{\prime} 34.539^{\prime \prime} \mathrm{W}$ & Lower Dells & 5 \\
\hline 74 & Staircase & $41^{\circ} 17^{\prime} 51.533^{\prime \prime} \mathrm{N} 89^{\circ} 1^{\prime} 34.539^{\prime \prime} \mathrm{W}$ & Lower Dells & 2 \\
\hline 75 & Flooding & $41^{\circ} 17^{\prime} 49.906^{\prime \prime} \mathrm{N} 89^{\circ} 1^{\prime} 27.915^{\prime \prime} \mathrm{W}$ & Lower Dells & 5 \\
\hline 77 & Flooding & $41^{\circ} 17^{\prime} 50.212^{\prime \prime N ~} 89^{\circ} 1^{\prime} 22.728^{\prime \prime} \mathrm{W}$ & Lower Dells & 5 \\
\hline 78 & Fallen Tree & $41^{\circ} 17^{\prime} 50.212^{\prime \prime} \mathrm{N} 89^{\circ} 1^{\prime} 22.728^{\prime \prime} \mathrm{W}$ & Lower Dells & 3 \\
\hline 79 & Rock Fall & $41^{\circ} 17^{\prime} 50.212^{\prime \prime} \mathrm{N} 89^{\circ} 1^{\prime} 22.728^{\prime \prime} \mathrm{W}$ & Lower Dells & 6 \\
\hline 80 & Staircase & $41^{\circ} 17^{\prime} 52.649^{\prime \prime} \mathrm{N} 89^{\circ} 1^{\prime} 28.441^{\prime \prime} \mathrm{W}$ & Lower Dells & 2 \\
\hline 81 & Flooding & $41^{\circ} 17^{\prime} 52.649^{\prime \prime} \mathrm{N} 89^{\circ} 1^{\prime} 28.441^{\prime \prime} \mathrm{W}$ & Lower Dells & 5 \\
\hline 82 & Fallen Tree & $41^{\circ} 17^{\prime} 51.389^{\prime \prime} \mathrm{N} 89^{\circ} 1^{\prime} 28.34^{\prime \prime} \mathrm{W}$ & Lower Dells & 3 \\
\hline 83 & Staircase & $41^{\circ} 17^{\prime} 50.914^{\prime \prime} \mathrm{N} 89^{\circ} 1^{\prime} 24.088^{\prime \prime} \mathrm{W}$ & Lower Dells & 2 \\
\hline
\end{tabular}




\begin{tabular}{|c|c|c|c|c|}
\hline 84 & Staircase & $41^{\circ} 17^{\prime} 38.134^{\prime \prime} \mathrm{N} 89^{\circ} 1^{\prime} 41.692^{\prime \prime} \mathrm{W}$ & Lower Dells & 2 \\
\hline 85 & Erosion & $41^{\circ} 17^{\prime} 38.242^{\prime \prime N ~} 89^{\circ} 1^{\prime} 42.664^{\prime \prime} \mathrm{W}$ & Lower Dells & 6 \\
\hline 86 & Flooding & $41^{\circ} 17^{\prime} 48.538^{\prime \prime} \mathrm{N} 89^{\circ} 1^{\prime} 40.263^{\prime \prime} \mathrm{W}$ & Lower Dells & 5 \\
\hline 87 & Trip/Slip & $41^{\circ} 17^{\prime} 50.496^{\prime \prime} \mathrm{N} 89^{\circ} 1^{\prime} 37.646^{\prime \prime} \mathrm{W}$ & Lower Dells & 2 \\
\hline 88 & Fallen Tree & $41^{\circ} 17^{\prime} 50.32^{\prime \prime} \mathrm{N} 89^{\circ} 1^{\prime} 36.544^{\prime \prime} \mathrm{W}$ & Lower Dells & 3 \\
\hline 89 & Erosion & $41^{\circ} 17^{\prime} 50.32^{\prime \prime} \mathrm{N} 89^{\circ} 1^{\prime} 36.544^{\prime \prime} \mathrm{W}$ & Lower Dells & 6 \\
\hline 90 & Trip/Slip & $41^{\circ} 17^{\prime} 29.429^{\prime \prime N} 89^{\circ} 1^{\prime} 35.281^{\prime \prime} \mathrm{W}$ & Lower Dells & 2 \\
\hline 91 & Trip/Slip & $41^{\circ} 17^{\prime} 51.079^{\prime \prime} \mathrm{N} 89^{\circ} 1^{\prime} 35.021^{\prime \prime} \mathrm{W}$ & Lower Dells & 2 \\
\hline 92 & Trip/Slip & $41^{\circ} 17^{\prime} 50.392^{\prime \prime} \mathrm{N} 89^{\circ} 1^{\prime} 31.223^{\prime \prime} \mathrm{W}$ & Lower Dells & 2 \\
\hline 93 & Trip/Slip & $41^{\circ} 17^{\prime} 49.661^{\prime \prime N} 89^{\circ} 1^{\prime} 30.741^{\prime \prime} \mathrm{W}$ & Lower Dells & 2 \\
\hline 94 & Trip/Slip & $41^{\circ} 17^{\prime} 49.625^{\prime \prime} \mathrm{N} 89^{\circ} 1^{\prime} 29.225^{\prime \prime} \mathrm{W}$ & Lower Dells & 2 \\
\hline 95 & Trip/Slip & $41^{\circ} 17^{\prime} 49.369^{\prime \prime} \mathrm{N} 89^{\circ} 1^{\prime} 28.214^{\prime \prime} \mathrm{W}$ & Lower Dells & 2 \\
\hline 96 & Trip/Slip & $41^{\circ} 17^{\prime} 28.32^{\prime \prime N ~} 89^{\circ} 1^{\prime} 26.072^{\prime \prime} \mathrm{W}$ & Lower Dells & 2 \\
\hline 97 & Trip/Slip & $41^{\circ} 17^{\prime} 50.248^{\prime \prime} \mathrm{N} 89^{\circ} 1^{\prime} 23.707^{\prime \prime} \mathrm{W}$ & Lower Dells & 2 \\
\hline 98 & Trip/Slip & $41^{\circ} 17^{\prime} 50.15^{\prime \prime N} 89^{\circ} 1^{\prime} 22.792^{\prime \prime} \mathrm{W}$ & Lower Dells & 2 \\
\hline 99 & Trip/Slip & $41^{\circ} 17^{\prime} 51.036^{\prime \prime} \mathrm{N} 89^{\circ} 1^{\prime} 22.133^{\prime \prime} \mathrm{W}$ & Lower Dells & 2 \\
\hline 100 & Trip/Slip & $41^{\circ} 17^{\prime} 52.224^{\prime \prime N} 89^{\circ} 1^{\prime} 25.474^{\prime \prime} \mathrm{W}$ & Lower Dells & 2 \\
\hline 101 & Trip/Slip & $41^{\circ} 17^{\prime} 52.318^{\prime \prime} \mathrm{N} 89^{\circ} 1^{\prime} 27.605^{\prime \prime} \mathrm{W}$ & Lower Dells & 2 \\
\hline 102 & Trip/Slip & $41^{\circ} 17^{\prime} 52.829^{\prime \prime} \mathrm{N} 89^{\circ} 1^{\prime} 28.718^{\prime \prime} \mathrm{W}$ & Lower Dells & 2 \\
\hline 103 & Trip/Slip & $41^{\circ} 17^{\prime} 54.665^{\prime \prime} \mathrm{N} 89^{\circ} 1^{\prime} 30.129^{\prime \prime} \mathrm{W}$ & Lower Dells & 2 \\
\hline 104 & Trip/Slip & $41^{\circ} 17^{\prime} 39.12^{\prime \prime} \mathrm{N} 89^{\circ} 1^{\prime} 43.068^{\prime \prime} \mathrm{W}$ & Lower Dells & 2 \\
\hline
\end{tabular}




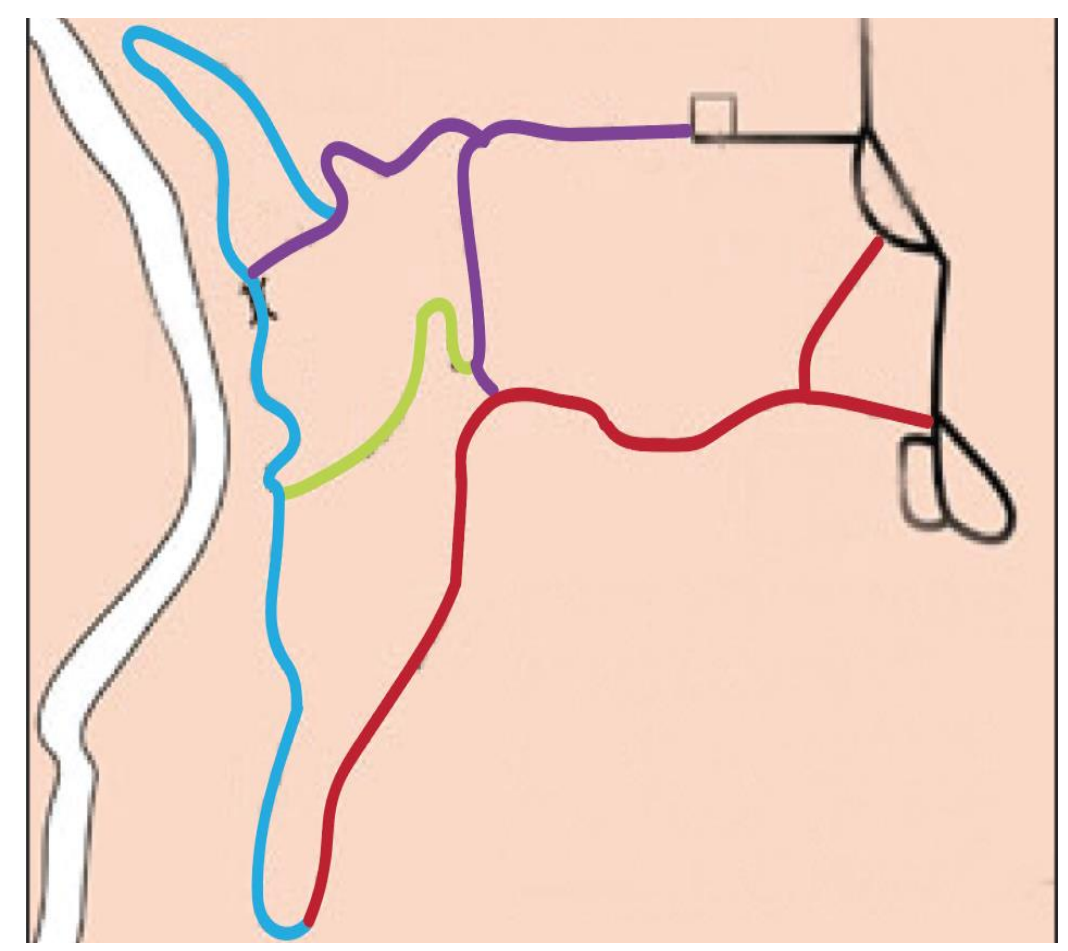

\begin{tabular}{|r|c|}
\hline$\underline{\text { Trail Names }}$ & Color \\
\hline Big Hill & Purple \\
\hline River Trail & Lt. Blue \\
\hline Ziggy Trail & Lt. Green \\
\hline Ridge Trail & Red \\
\hline
\end{tabular}

Figure 6: Shows a map of the trails that were hiked in the Vermilion River Area of the park. The table to the left acts as the legend. 


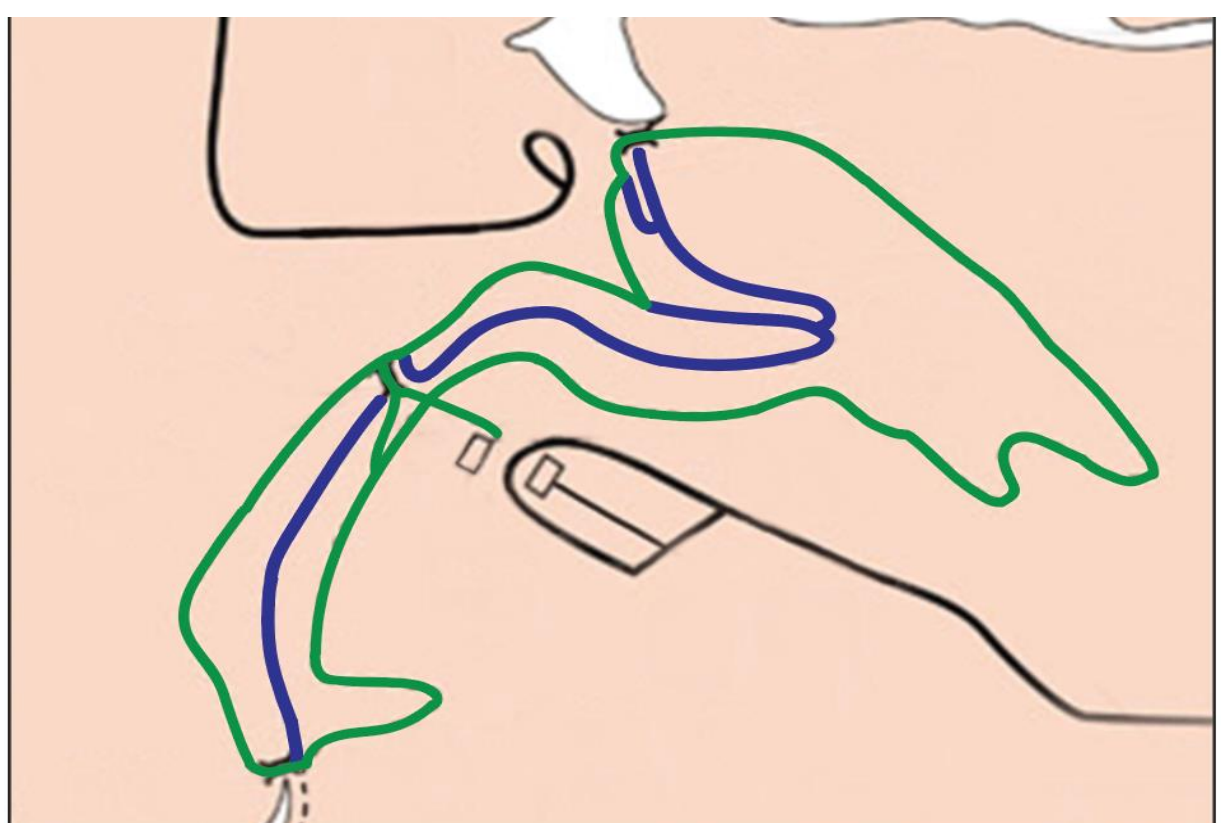

\begin{tabular}{|c|c|}
\hline$\underline{\text { Trails }}$ & $\underline{\text { Color }}$ \\
\hline Upper Dells & Green \\
\hline Lower Dells & Blue \\
\hline
\end{tabular}

Figure 7: The figure above shows a map of the trails of the Dells Area of the park. The legend is located to the left. 
Appendix B: Examples of Hazards

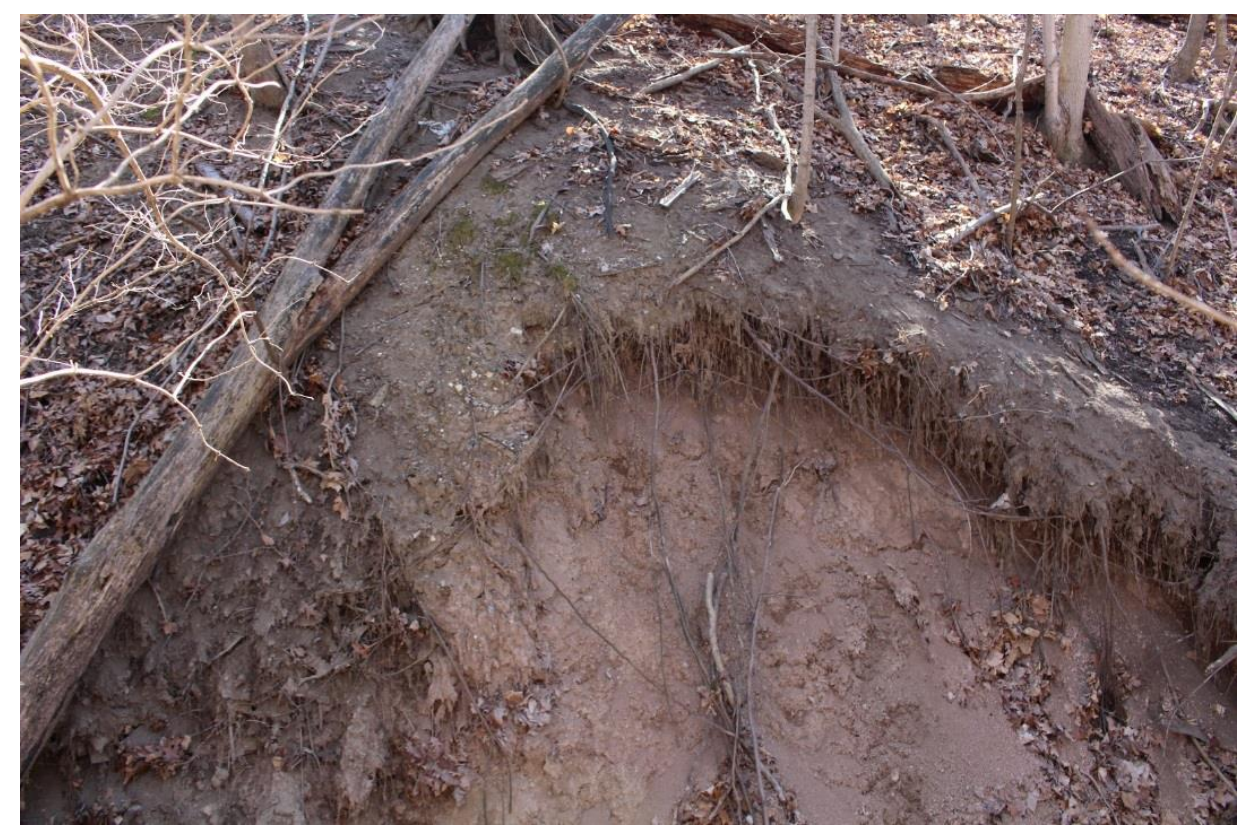

Figure 8: This photo shows an example of an erosional surface. 


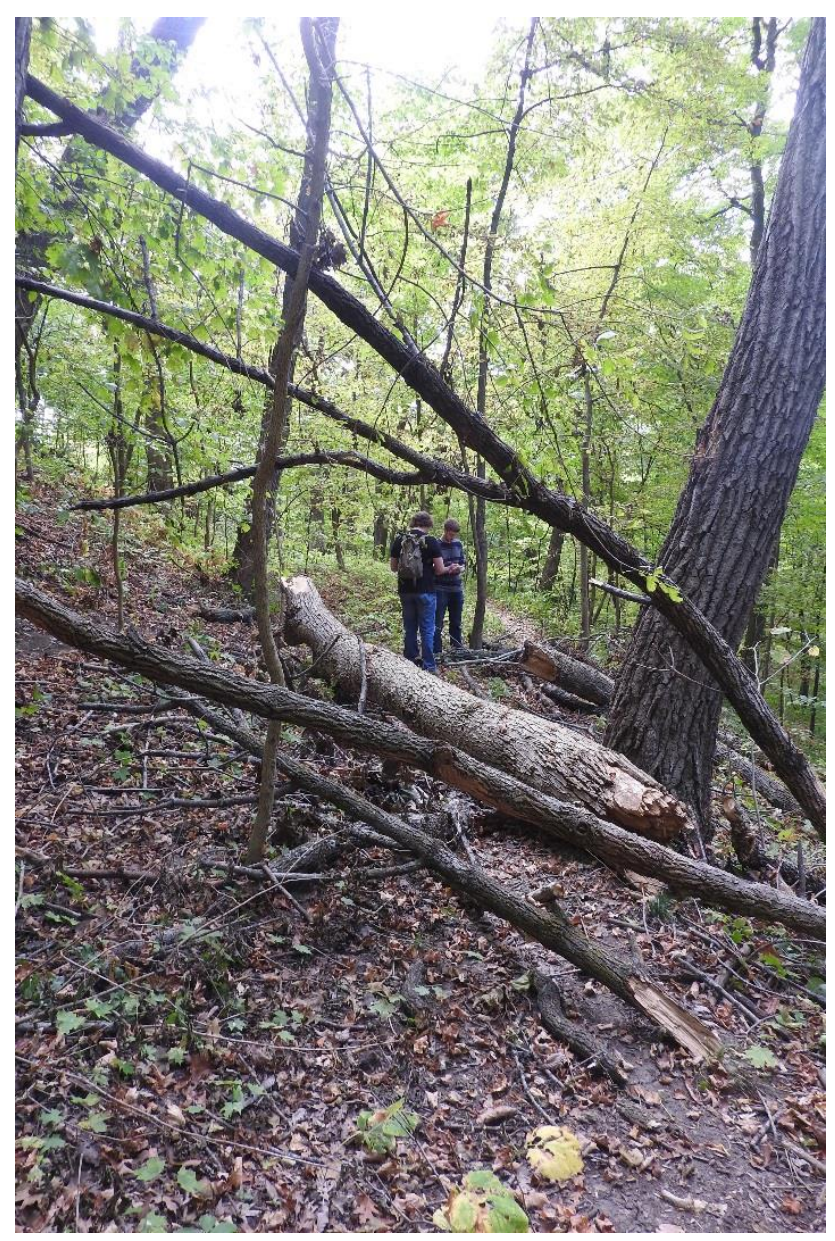

Figure 9: This is a photo of a fallen tree. This caused the park to divert the trail around the tree. 


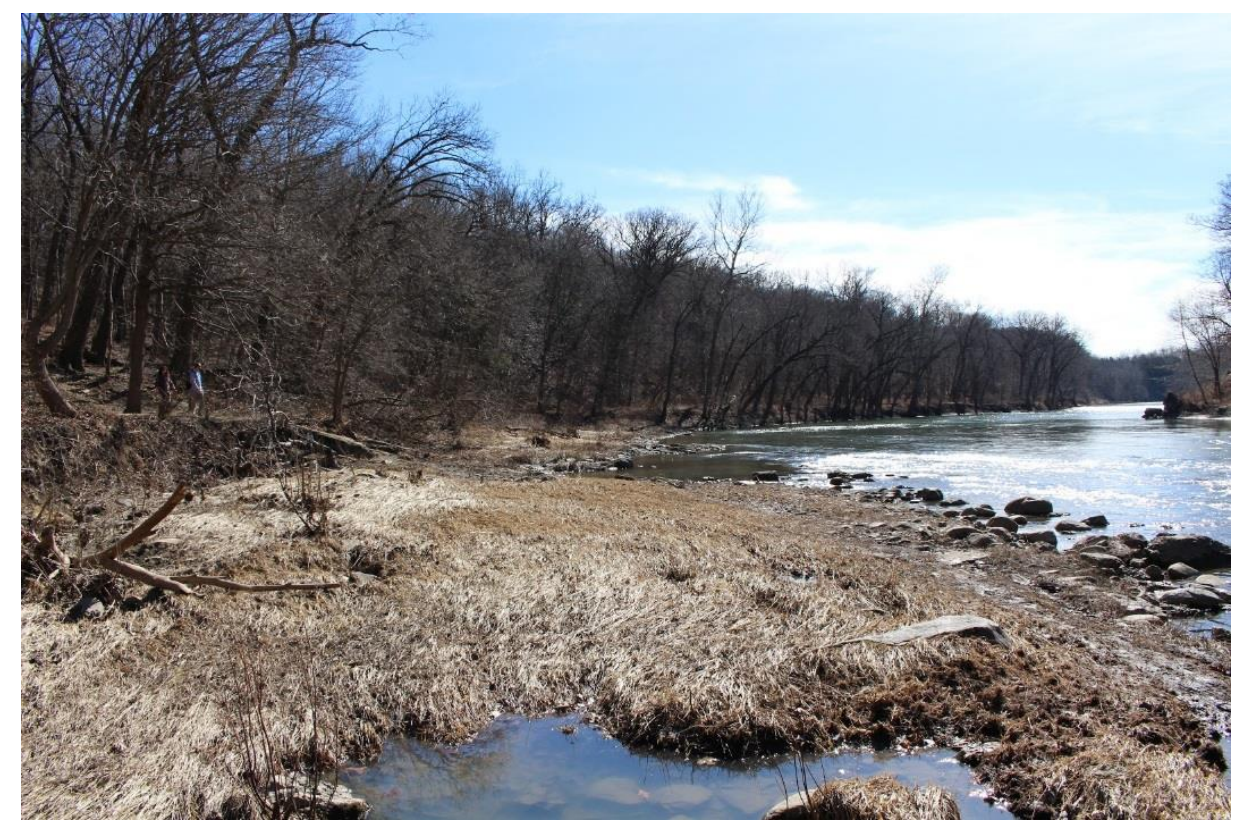

Figure 10: This photo represents a flooding hazard.

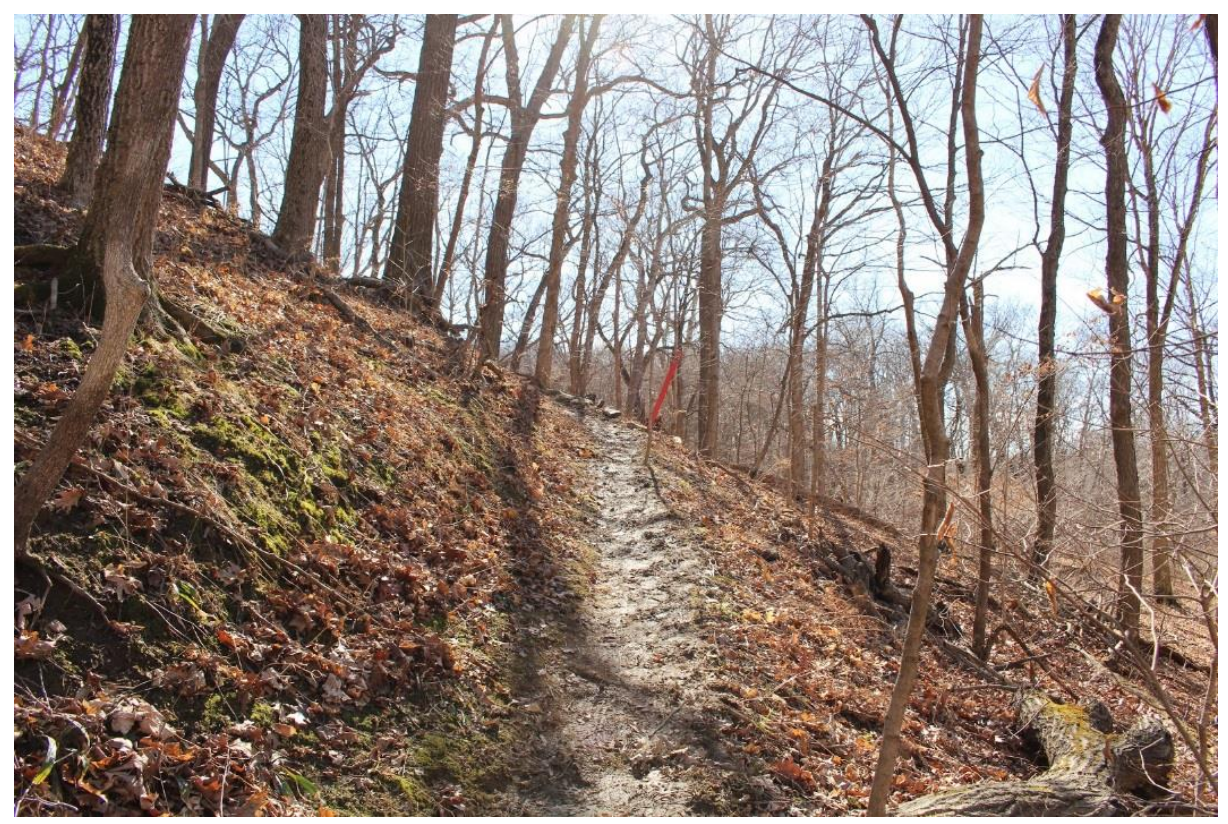

Figure 11: This is an example of a steep climb. 


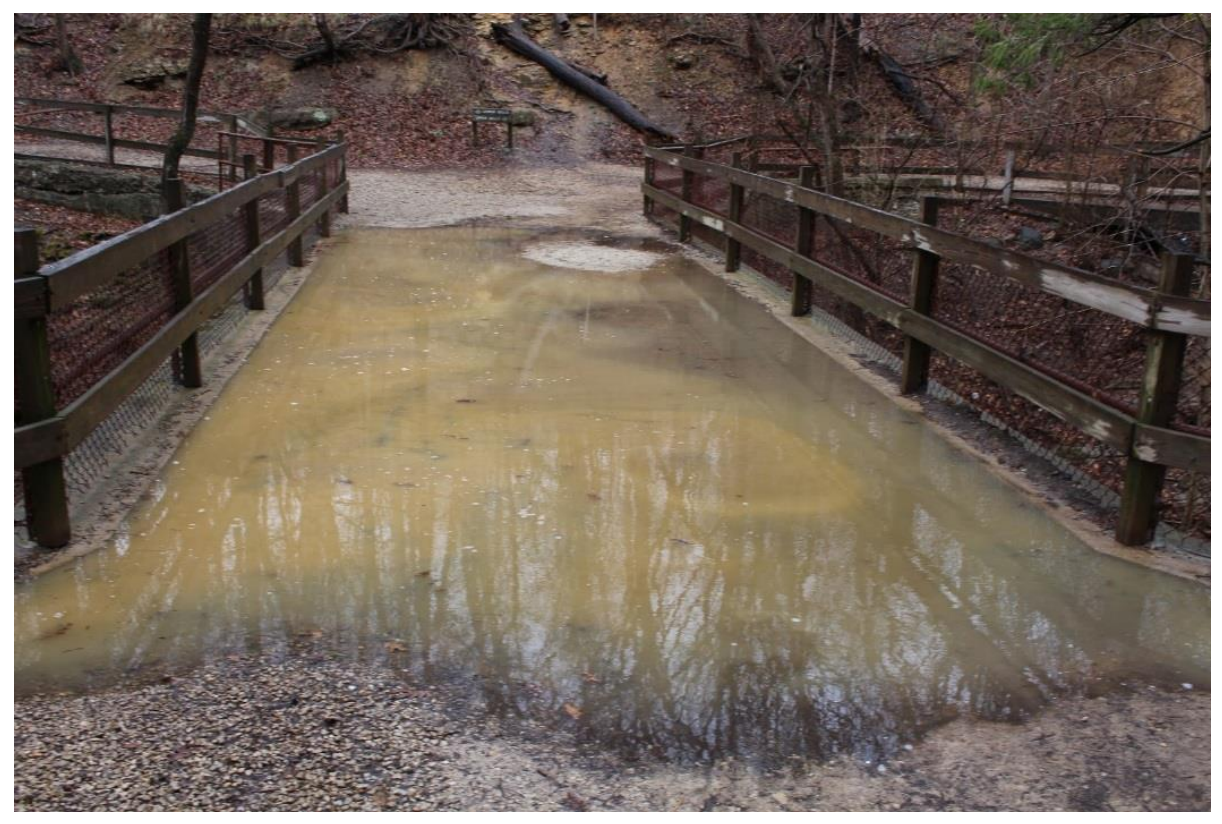

Figure 12: This is an extreme example of flooding on a bridge. The bridge had no drainage system installed, thus, stopping water from dispersing.

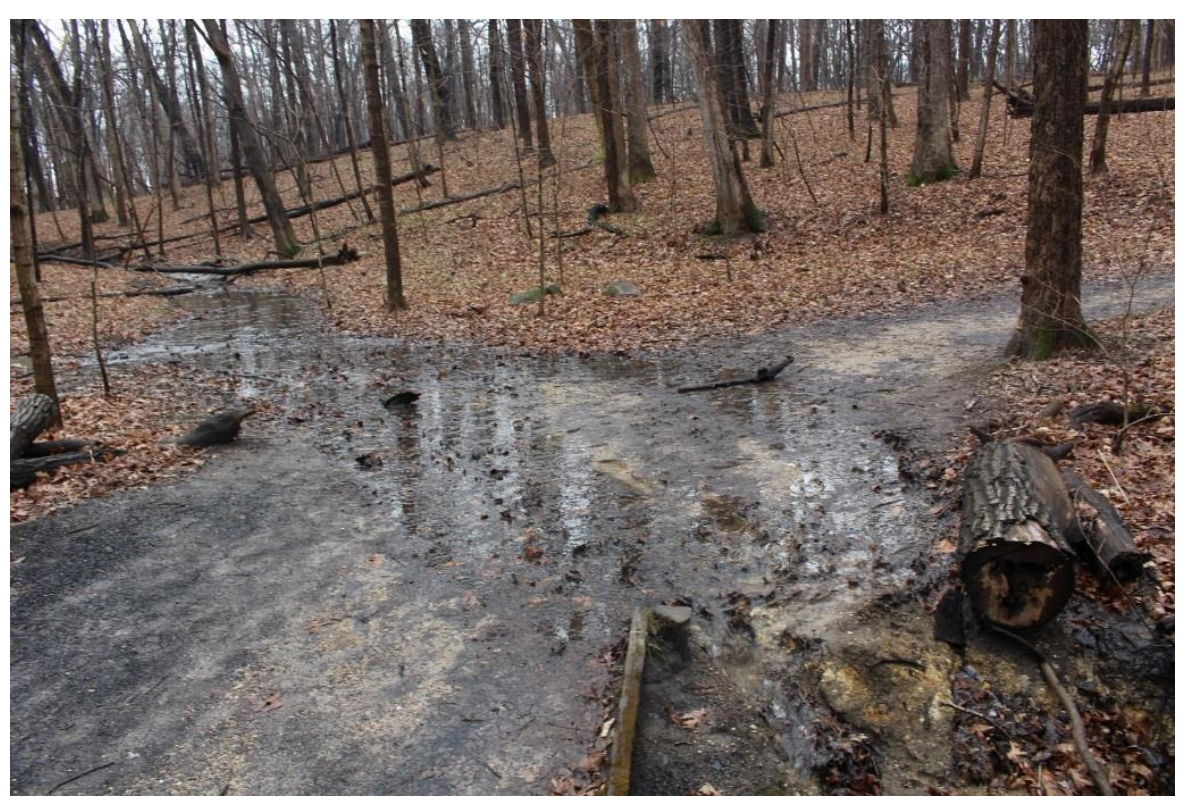

Figure 13: This is an example of a flooded pathway. This pathway became flooded due to a lack of drainage. 


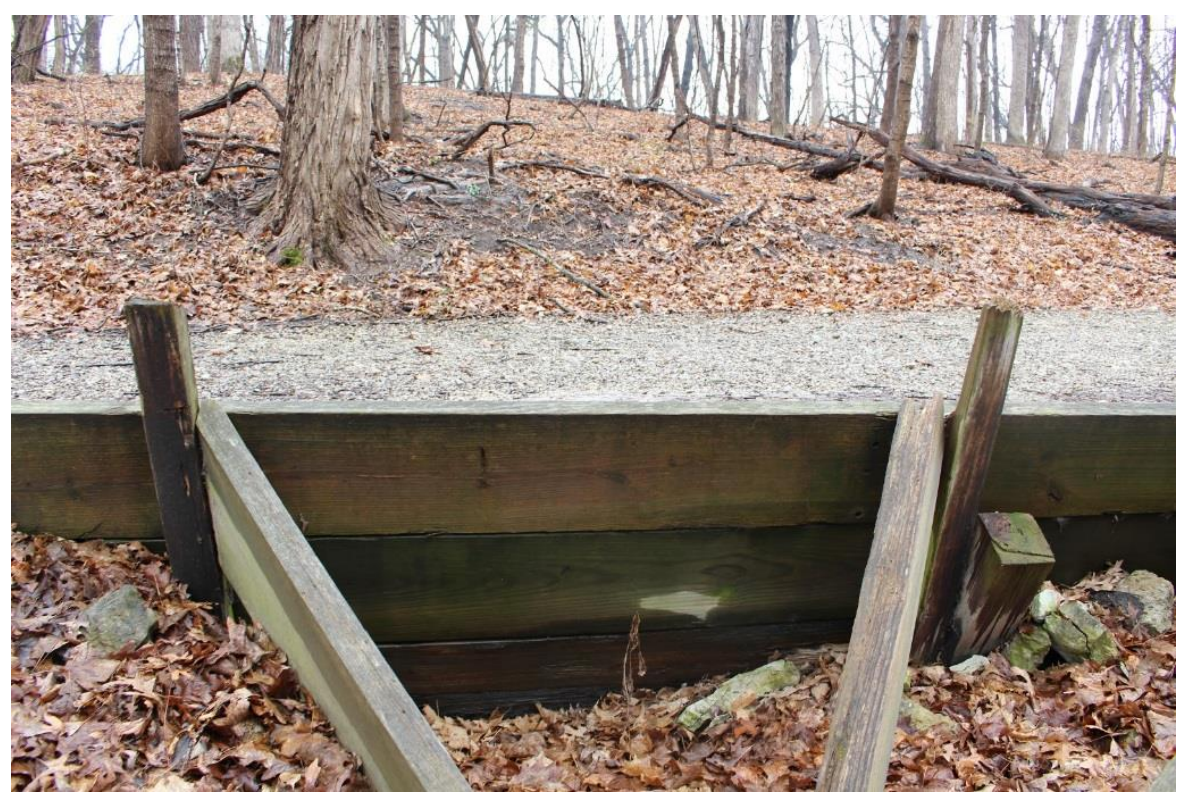

Figure 14: This photo shows a perfectly stable support structure, holding the pathway in.

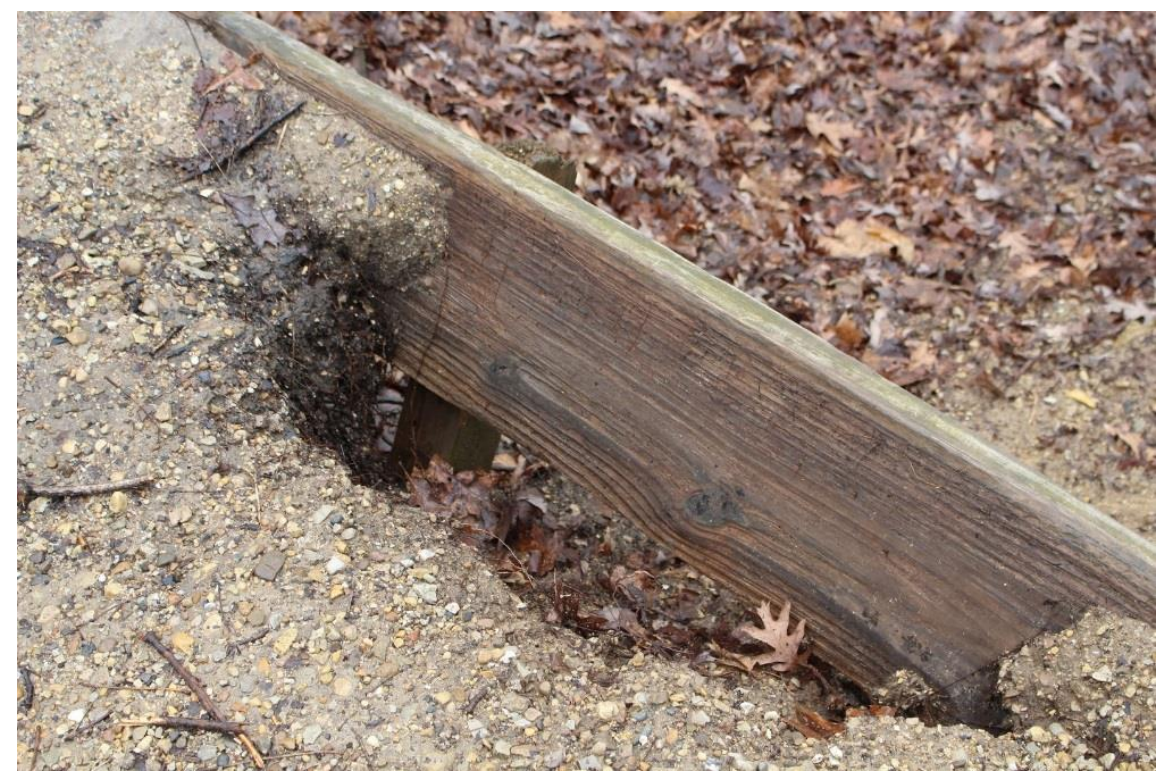

Figure 15: This photo shows how the support structure is failing as the water has removed the soil and a hole has developed. 


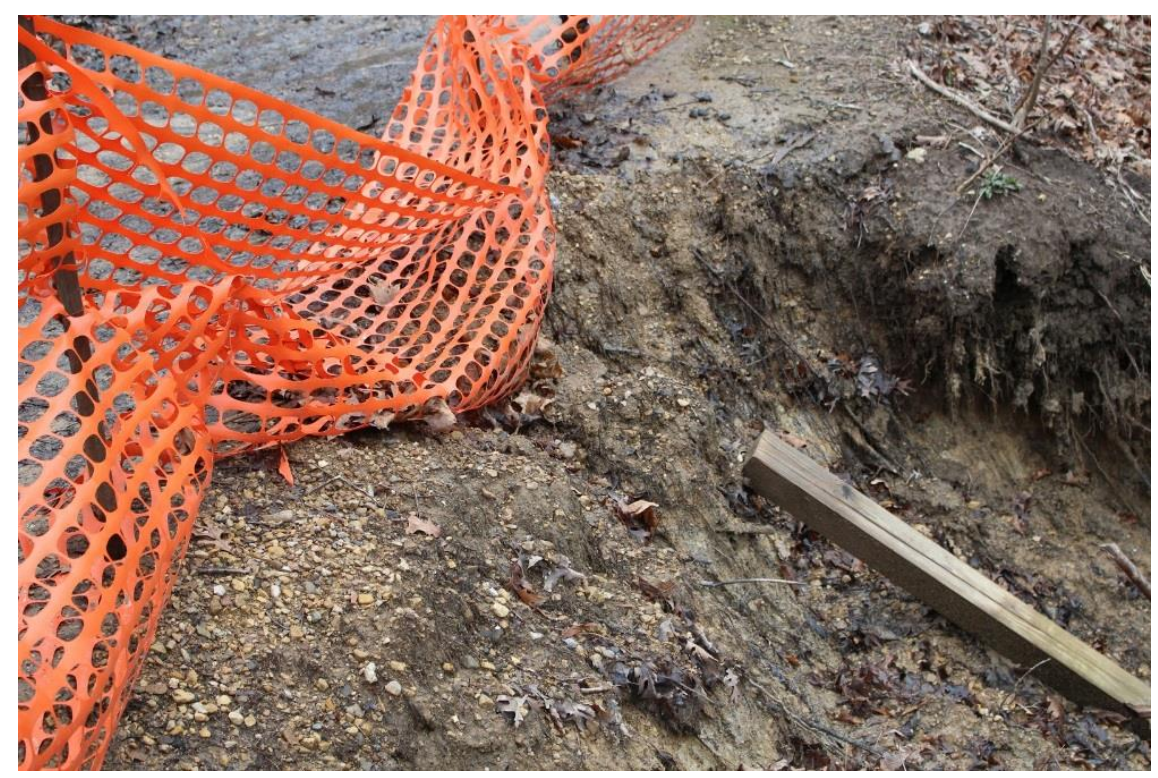

Figure 16: This photo shows a failed support. The park had to put up this orange fence to warn the public of the drop off that was created by erosion.

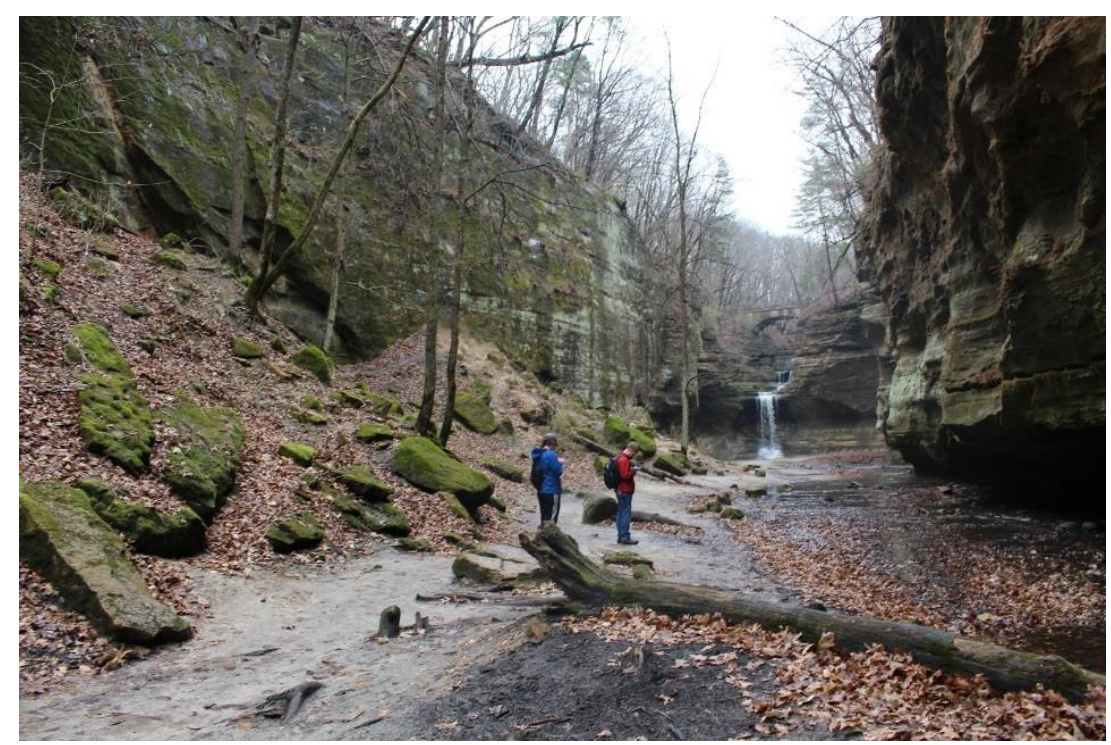

Figure 17: This photo shows one of the rockfalls that are found on the Lower Dells path. The picture also shows the 45 foot canyon walls that run parallel with the Upper Dells trail. That would be an example of a shear surface. 


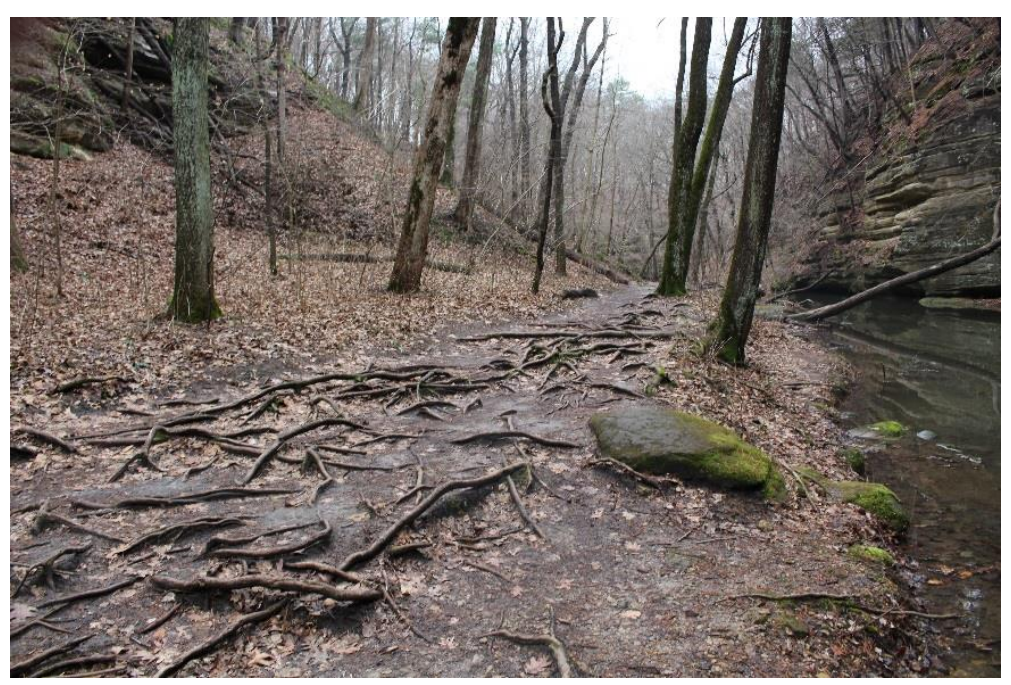

Figure 18: This figure shows the effects of erosion on the path exposing the tree roots causing a trip/slip.

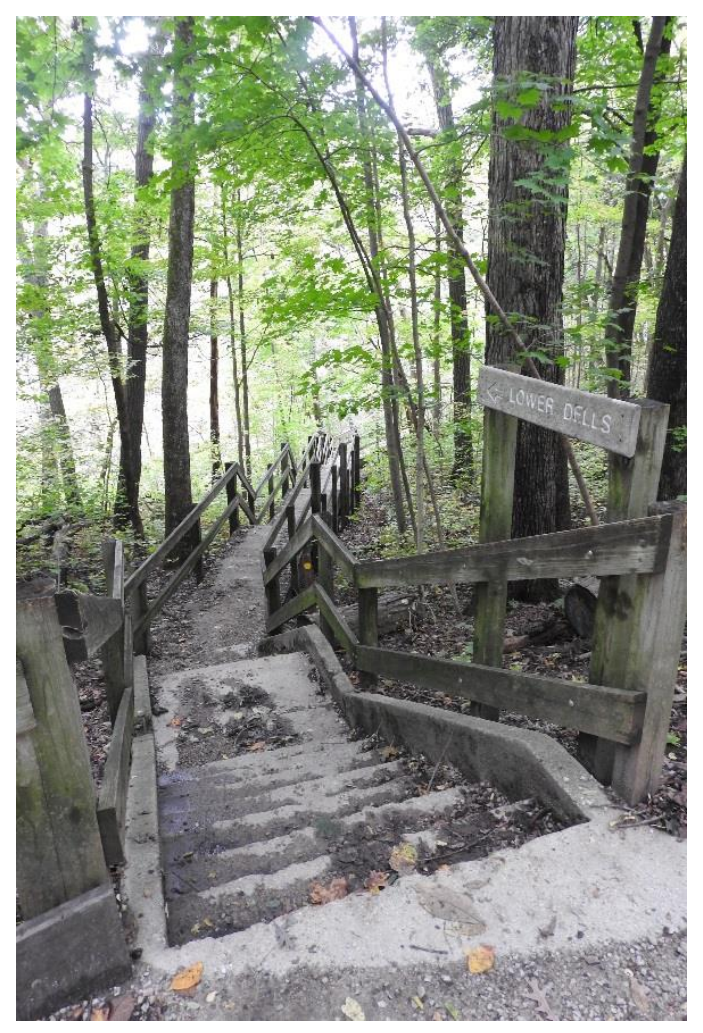

Figure 19: This picture depicts one of the many staircases in the state park. The only way to enter the Lower Dells is by taking the stairs down. 